\title{
Femine Body in the Mass Culture of Iran: between Nudity and Marginalization
}

\section{Maksym W. Kyrchanoff}

Voronezh State University. Voronezh, Russia. Email: maksymkyrchanoff[at]gmail.com

\begin{abstract}
The author analyses the problems of visualisation and marginalisation of female corporeality in developments of Iranian political and cultural identity from the early modernisation project of the $19^{\text {th }}$ century and the radical modernisation of the 1920s - 1970s to the Islamic Revolution of 1979, which changed significantly the vectors and trajectories of the visualisation of the female body in public spaces and the discourse of Iranian culture. The author believes that Iran / Persia in the $19^{\text {th }}$ century belonged to the number of Muslim countries that were under stable European influences. Russia and Great Britain became the main sources of cultural changes. Cultural exchange with these countries stimulated changes in Persian identity. The author analyses the features of corporeality in the visual art of Iran from the Qajars to the Islamic revolution and its mutations during the process of radical Islamisation of the social life inspired by it. The author believes that the early modern project of the Qajars was the first attempt to visualise female corporeality and map in the centre of cultural coordinates which in fact simulated European discourse. The identity project of the Pahlavi period became an attempt to transform and adopt Western concepts to the Iranian national canon. The Islamic Revolution of 1979 marginalised the visual and visible forms of female corporeality, presented earlier in public and cultural spaces. The project of Islamisation inspired subordination of the female body, marginalising attempts to visualise in ways Western intellectuals did it. Modern feminine corporeality in Iranian culture develops as a dichotomy of official religious identity and its secular alternative, represented by the "high" cultural segments of the consumer society. The author analyses how and why Western strategies of visualisation of female corporeality coexist with its religious rejection. It is assumed that the Iranian mass culture assimilated Western practices of visualising femininity, although the official cultural discourse continues to reproduce the canon of the body imagined as predominantly religious construct.
\end{abstract}

\section{Keywords}

Iran; Qajars and Pahlavi; modern and modernization; body; female body; femininity; female breasts and decollete in Iranian culture; "Qajar decollete" as an invention of traditions

This work is licensed under a Creative Commons «Attribution» 4.0 International License 


\title{
Феминная телесность в массовой культуре Ирана: между обнажением и маргинализацией
}

\author{
Кирчанов Максим Валерьевич \\ Воронежский государственный университет. Воронеж, Россия. \\ Email: maksymkyrchanoff[at]gmail.com
}

\section{Аннотация}

Автор анализирует проблемы визуализации и маргинализации женской телесности в развитии иранской политической и культурной идентичности от проекта ранней модернизации XIX века и радикального модернизационного проекта 1920 - 1970-х гг. до Исламской революции 1979 г., которая существенно изменила векторы и траектории визуализации женского тела в публичных пространствах и дискурсе иранской культуры. Автор полагает, что Иран / Персия в XIX веке принадлежал к числу мусульманских стран, которые пребывали под устойчивым европейским влиянием, а основными источниками культурных перемен были Россия и Великобритания, так как культурный обмен с этими странами стимулировал изменения в идентичности. Автор анализирует особенности представленной телесности в визуальном искусстве Ирана от Каджаров до Исламской революции и вдохновленной ей процесса радикальной исламизации жизни общества. Автор полагает, что ранний модерный проект Каджаров стал первой попыткой визуализации женской телесности в системе координат, которая симулировала и имитировала европейский культурный дискурс, а проект идентичности периода правления Пехлеви стал попыткой трансформации западных концептов в иранский национальный канон. Исламская революция 1979 г. маргинализировала визуальные формы женской телесности, видимые и присутствующие в общественных и культурных пространствах, так как проект исламизации и субординации женского тела маргинализировал попытки его визуализации в западной системе координат. Современная феминная телесность в иранской культуре развивается как дихотомия официальной религиозной идентичности и ее светской альтернативы, представленной высшими сегментами общества потребления. Поэтому автор анализирует, как и почему западные стратегии визуализации и актуализации телесности сосуществуют с ее религиозным неприятием. Предполагается, что иранская модель массовой культуры ассимилировала западные практики визуализации феминности, хотя официальный культурный дискурс продолжает воспроизводить канон тела, воображенного в преимущественно религиозной системе координат.

\section{Ключевые слова}

Иран; Каджары и Пехлеви; модерн и модернизация; тело; женское тело; феминность; женская грудь и декольте в иранской культуре; «каджарское декольте» как изобретение традиций

Это произведение доступно по лицензии Creative Commons «Attribution» («Атрибуция») 4.0 Всемирная 


\section{Введение}

На протяжении своей многовековой истории Персия / Иран ${ }^{1}$ имели различные, но, как правило, всегда многоуровневые и разнообразные отношения с внешним миром, включая те общества и страны, которые в историографии традиционно определяются как «европейские» или в более широком контексте воспринимаются как «западные». Несмотря на наличие разнообразных контактов и отношений на политическом и экономическом уровнях, Иран практически всегда был в состоянии сохранять свою уникальную культурную и религиозную идентичность. Если на определенных этапах истории основой таковой был зороастризм, то исламизация не смогла в полной мере интегрировать индоевропейцев иранцев в мир арабского сунитского ислама, так как персы стали шиитами.

В традиции западной историографии, вероятно, заложенной еще древнегреческими историками, утвердилась традиция последовательной оппозиции и противопоставления персов и греков, что позднее было отягощено политическими мифами и религиозными стереотипами. Как результат, к концу XVIII-началу XIX века Персия / Иран в западной культурной и интеллектуальной традиции стали составными компонентами конструкта, известного как «Ориентализм». На Персию, как и другие мусульманские регионы, проецировались соответствующие мифы Другости и Инаковости, которые в одинаковой степени распространялись на культурные и религиозные особенности жизни персов, которые европейскими авторами нередко редуцировались до одних из мусульман.

Начавшаяся в конце XVIII столетия конфронтация Ирана с Российской Империей, как части Европы, содействовала не только дальнейшему развитию такого образа, но и его продвижению на Западе при российском культурном посредничестве, а убийство в Тегеране дипломатов и служащих российской миссии в 1829 году только стимулировало распространение именно таких образов. Тем не менее, иранская реальность XIX века была все же далека от таких стереотипных представлений, так как начавшиеся отношения с Россией и другими европейскими странами не только постоянно развивались, но и содействовали проникновению в персидскую культуру западных элементов.

Иран в XIX столетии в определенной степени может быть поставлен в один ряд с государствами-империями, так как, вероятно, именно империя была универсальной формой государственности того времени. Все империи, в большей или меньшей степени, сталкивались с угрозами как модернизации, так и архаизации, что вынуждало элиты адаптировать имперскую модель к постоянно изменяющимся внешним условиям. Персия не стала исключением из этой универсальной логики развития и трансформации имперских

1 В тексте данной статьи термины «Иран» и «Персия» / «иранский» и «персидский», «персы» / «иранцы» используются как синонимы дабы избежать излишнего, стилистически неудобного, повторения. 
систем, что привело иранские элиты к пониманию и осознанию как вынужденности, так и неизбежности модернизации, одной из форм которой и стала ассимиляция западного культурного опыта в Иране, протекавшая при посредничестве как российского, так и английского культурного влияния. Этот процесс оказался крайне медленным и обладал значительными особенностями, связанными с тем, как уникальная иранская культура адаптировала «под себя» внешние западные влияния.

Одной из форм такого культурного влияния стало изменение отношения к телесности. Традиционные канон персидской культуры средневековья, который возник под влиянием шиитского ислама, предусматривал наличие ряда ограничений на визуализации в искусстве тела, в первую очередь женского и обнаженного, что оказала существенное влияние и воздействие на формы визуального представления телесности в иранской культуре.

Поэтому, в центре внимания в данной статье будут проблемы визуализации феминной телесности в дискурсе персидской / иранской культуры от периода Каджаров до попыток и последствий ее исламизации.

Целью статьи является анализ тех культурных тактик и стратегий, которые персидские авторы использовали для визуализации тела, что привело к появлению уникальной культурной изобретенной традиции изображения феминной телесности, которые нередко носили в значительной степени фантастический характер, не отражая реалий жизни представителей персидской элиты, для которых подобные произведения каджарского искусства и были предназначены.

Исходя из этого, задачи статьи могут быть сведены к следующему: анализ феминной телесности в визуальном искусстве периода Каджаров в контекстах т.н. «каджарского декольте»; изучение вестернизации визуальной женской телесности в иранской культуре XX века; анализ проблем маргинализации визуализированной феминной телесности после Исламской революции; и изучение проблем актуализации феминной телесности в современной иранской версии культуры общества потребления.

\section{Акутальность}

Анализ проблем как представленности, так и маргинализации феминной телесности в истории иранской культуры XIX - XX вв. как истории идей, интеллектуальной истории или археологии идей представляется актуальным в силу целого ряда факторов.

Во-первых, данная проблематика в историографии, в отличии от других аспектов истории иранской культуры, изучена в меньшей степени. Во-вторых, сама культурная политика правящего режима в Исламской Республике Иран направлена на последовательную маргинализацию визуального искусства Ирана XIX и XX веков до Исламской революции, так как его произведения практически невозможно интегрировать в доминирующий канон, основанный 
на религиозной системе координат, что делает практически любые визуальные изображения женской телесности не только нежелательными, но и маргинальными и недопустимыми с точки зрения религиозной морали.

В-третьих, на современном этапе в ряде стран Запада предметы иранского искусства XIX и XX веков, которое в самом Иране статуса официального не имеет, начинают пользоваться спросом на аукционах, специализирующихся на продаже предметов искусства и антиквариата. В-четвертых, европейские и американские музеи и частные коллекционеры являются владельцами уникальных и значительных коллекций предметов изучаемого искусства, что свидетельствует о наличии устойчивого интереса к иранской истории и культуре XIX - XX веков, а также проявляется в периодически организуемых выставках, одна из которых «Роскошь Заката: Иран эпохи Каджаров», например, открылась 15 мая 2021 г. в Музее Востока в Москве.

В целом, автор полагает, что эти факторы в комплексе придают актуальность изучению проявлений феминной телесности в иранском искусстве двух столетий, что позволяет рассмотреть не только основные формы репрезентации визуализированной феминности, но и проанализировать как ее генезис, трансформации и мутации, а также маргинализацию в результате исламской революции.

\section{Историография}

Если истории персидской / иранской культуры посвящена значительная академическая литература, которая охватывает несколько тысячелетий уникального культурного опыта в целом, то проблемы феминной (и не только) телесности принадлежат к числу практически неизученных проблем. Немногочисленные попытки актуализации этой тематики представлены в текстах, сфокусированных на изучении содержательно иных проблема истории иранской государственности в ее имперской модели, истории политической и культурной модернизации, проблем культурной политики исламской революции.

В современной историографии сложились различные модусы описания тела и телесности как в рамках исторической и культурной антропологии, так и в контекстах теории и истории моды, но и в этой ситуации внешнего историографического благополучия следует признать, что число текстов о феминной телесности и женской моде с ней связанной в странах с доминированием мусульман, а тем более - в исламских республиках, количественно несопоставимы с работами о телесности в европейском, американском и российском культурном дискурсах. Поэтому, «другие способы и системы формирования модного тела по-прежнему включают в глобальный дискурс о моде лишь в рамках системы, построенной на современности и колониальности, а не как самостоятельные явления, с собственными определениями, эстетикой и эпистемологическим аппаратом» (Янсен, 2021), что не только 
локализует иранские сюжеты в современных штудиях тела на периферии, но и косвенно свидетельствует как нужности их изучения, так и необходимости ревизии западноцентричного подхода.

В этой историографической ситуации вопросы и проблемы истории визуализации и репрезентации феминной телесности в иранской культурной традиции XIX и XX веков не успели стать предметом самостоятельных штудий, несмотря на значительный междисциплинарный потенциал данной проблематики и открывающиеся возможности применения и использования тех методов, которые, безусловно, могли бы привести историков интересным и оригинальным результатам.

\section{Методология}

Анализ проблем истории визуализации и репрезентации феминной телесности в иранской культуре представляется наиболее перспективным в случае одновременного использования методов, которые теоретически могут стать частью междисциплинарного синтеза.

Во-первых, автор полагает, что в рамках изучения визуализации женской телесности в рамках иранского культурного канона изучаемого периода возможно использование концепта «изобретения традиций» (Hobsbawm, Ranger, 1983), в рамках которого практики, тактики и стратегии иранских живописцев XIX века и дизайнеров XX столетия могут быть описаны как различные формы изобретения и дальнейшего воспроизводства культурных традиций путем их тиражирования.

Во-вторых, различные версии и модификации семиотического подхода также представляются вполне применимыми и эффективными для изучения визуализации и актуализации феминной телесности в иранской культурной традиции изучаемого периода, если тело и его отдельные части воспринимать и интерпретировать как культурные знак или соответствующие культурные знаки - поэтому различные формы и стратегии как позиционирования телесности в искусстве, так и ее более поздние критические и академические прочтения представляют собой составные элементы процесса семиозиса интерпретации тела как знака, что влечет за собой производство и воспроизводство соответствующих смыслов.

В целом, использование такого методологического инструментария, как полагает автор, может оказаться не только эффективным для изучения истории визуализации и актуализации феминной телесности в контекстах иранской культуры, но и может привести к компромиссу между нарративными стратегиями и тактиками интерпретации, с одной стороны, и попытками переосмысления культурного опыта через призму визуальных источников, с другой. 


\section{«Каджарское декольте»: художественная реальность Ирана или первая изобретенная традиция (прото)массовой культуры}

Анализируя особенности проявления феминной телесности в живописи Ирана эпохи Каджаров, во внимание следует принимать ряд факторов, связанных с особенностями как моды, так и стратегиями позиционирования гендера в культурных пространствах.

Формальные идеалы красоты в Персии XIX века в значительной степени отличались как от современных иранских, так и европейских. Во-первых, в качестве идеального типа маскулинного героя позиционировался молодой человек, подражающий женщине. Во-вторых, идеальной феминной героиней считалась женщина имитирующая визуально мужчину. В-третьих, одним из распространенных образов в каджарской живописи стала девушка, внешность которых предусматривала несколько обязательных атрибутов - луноликое лицо, миндалевидные глаза, искусственные черные мушки, маскулинная монобровь. В-четвертых, значительная часть произведений иранской живописи периода Каджаров фиксирует и визуализирует предметы моды того времени (Diba, 2012), включая эгет (украшения головного убора), пирохан (тонкая рубаха), базубанды (наплечные браслеты), шальвары (пышные цветные штаны). В-пятых, феминное тело (руки и ноги) могли обильно украшаться хной (Гасымов, 2016; Григорьева, 2021).

Анализ феминной телесности в визуальном искусстве периода Каджаров, вероятно, следует начать с проблемы т.е. «каджарского декольте».

Единого определения этого явления в научной литературе по истории иранской живописи не существует, но под «каджарским декольте» можно понимать не только попытки визуализации женской телесности персидскими художниками второй половины XIX века, но и более поздние рефлексии и спекуляции как иранских, так и зарубежных авторов относительно реальности или нереальности существования этого явления как части женской моды в «высокой культуре» Ирана периода пребывания у власти династии Каджаров.

Что такое «каджарское декольте»?

В самом общем плане под «каджарским декольте» следует понимать набор художественных приемов и практик, который использовался иранскими художниками (Pakbaz, 1396 / 2017) для визуализации обнаженной феминной телесности. При этом во внимание следует принимать и доминирующую роль шиизма в политической и культурной жизни Ирана XIX века и в этом контексте возникают вопросы относительно реальности и историчности «каджарского декольте», так как одежда, пусть и предназначенная для ношения исключительно в женской части дома, вряд ли предусматривала полное обнажение груди. «Каждарское декольте», несмотря на его маловероятность реального использования как элемента платья, можно воспринимать как элемент того, 
что в исследовательской литературе (Деннике, 1938) определяется как «каджарский стиль» (Амиранишвили, 1940; Robinson, 1958).

Реальное использование «каджарского декольте» представляется маловероятным не только в силу шиитского основания иранской культуры, но и по причине того, что в более модернизированной и секуляризированной Европе современного Каджарам периода использование декольте в женской моде было связано с определенными ограничениями и не предусматривало визуального открытия груди. Тем не менее, явление «каджарского декольте» фиксируется на ряде картин периода Каджаров.

Генезис такого явления моды, реальной или воображаемой, то есть социально и культурно предписываемой, как «каджарское декольте», остается дискуссионным.

С одной стороны, ряд возможных объяснений появления визуальных образов декольте и обнаженной женской груди в мусульманской стране, где значительная роль в функционировании идентичности принадлежала не светскому искусству (Gary, 1392 / 2013), а особому типу шиитской религиозности, связан с возросшим именно в XIX веке европейским влиянием и тем, что персидские художники (Abdi, 1384 / 2005) получили (пусть и ограниченную) возможность ознакомиться с образцами европейского искусства (Tāvusi, 1391 / 2012). К середине XIX века европейская культура обрела значительный опыт визуализации феминной телесности, в том числе - и обнаженной, который в шиитском Иране отсутствовал, а его отдельные проявления в персидские культурные контексты проникали крайне медленно.

С другой стороны, истоки такого явления как «каджарское декольте» могут быть локализованы в рамках истории древневропейского искусства, так как в значительной степени аналогичные мотивы демонстрирует религиозная скульптура крито-микенской цивилизации, в частности - т.н. Богини со змеями (иллюстр. 1 - 4), но вопрос знакомства иранских художников с этим пластом европейской культурной истории остается дискуссионным. К тому же, большая часть находок подобных скульптурных изображений на Крите датируется началом XX века. В этом контексте, средиземноморский генезис «каджарского декольте» представляется более чем сомнительным, хотя некоторые авторы все же полагают, что подобные полотна актуализировали «нежное, томное, игривое, а в некоторых случаях даже эротическое содержание» (Ибрагимов, 2013:30).

В этом контексте представляется более логичным и уместным интерпретировать «каджарское декольте» (иллюстр. 5 - 6) не как часть условно реальной и повседневной женской моды Ирана XIX века, но как культурный и интеллектуальный конструкт, одну из первых изобретенных традиций актуализации и визуализации обнаженного феминного тела. «Каджарское декольте» представлено в качестве атрибута женской моды не только на ряде картин иранских авторов XIX столетия (иллюстр. 7 - 9), которые, вероятно, были предназначены для представителей высшего или высшего среднего класса персид- 
ского общества. По мнению некоторых российских исследователей (Васильева, 2017), подобные элементы можно обнаружить и в иранской живописи более раннего времени, но они фантастичны, отражая европейское влияние, не будучи вдохновлёнными реальными атрибутами персидской моды. Поэтому культурная циркуляция «каджарского декольте» (иллюстр. 10 - 11) как модного элемента или изобретенной традиции, вероятно, была ограничена.

Несмотря на это, в XIX веке образы «каджарского декольте» фиксируются и на более дешевых изделиях из папье-маше (иллюстр. 12), что, вероятно, указывает на постепенно углубляющие процессы секуляризации культурного пространства и начало относительно массового тиражирования узнаваемых и продаваемых визуальных образов феминной телесности. Несмотря на формально нереальность использования такого элемента как «каджарское декольте» в реальности, его образы как картинах иранских авторов отражают некоторые стереотипные представления персидского общества об идеальном женском теле и понятии «женская красота». Кроме этого, картины с изображением «каджарского декольте» фиксируют и некоторые реальные проявления и формы женской моды высшего политического класса в Иране.

В целом, вопрос о реальности или нереальности существования такого явления как «каджарское декольте» представляется второстепенным в контексте того влияния, которое эта изобретенная культурная традиция оказала на социальную историю телесности в Персии. Само явление «каджарского декольте» в искусстве Ирана важно в том смысле, что именно оно стало одной из первых попыток визуализировать женское тело вне традиционной системы координат для страны, в составе населения которой численно доминировали мусульмане. Женская «портретная» живопись периода Каждаров, вероятно, к классическому портрету отнесена быть не может, но она содействовало деконструкции женской феминности из традиционной системы координат, и, поэтому, «женское тело было снято с холста и введено в трехмерность перформанса, тело все еще должно было оставаться сдержанным, замкнутым, гладким, легким на вид и легким в обращении, очень похожим на статую или даже предмет потребления. Женское тело было гораздо более закодировано понятиями красоты и отвращения, чем его мужской аналог. Эти культурные коды гарантировали, что тело не нарушает своих границ, не делает видимыми свое внутреннее естество и при этом остается пассивным и сдержанным» (Цырлина, 2018), но эта вторичность, пассивность, сдержанность и подчиненность женского тела, были в персидской культуре Каджаров явлениями временными, так как визуализация частично обнаженного, декольтированного, женского тела стала шагом к актуализации самой феминной телесности в целом, результаты которой стали в большей степени заметны в XX веке, в рамках радикального модернизационного проекта Пехлеви.

Во-первых, оно стало одно из первых изобретенных традиций, что свидетельствовало о начале содержательно нового этапа в истории иранской иден- 
тичности, связанного с ее постепенной секуляризацией и вестернизацией. «Каджарское декольте», вероятно, может быть поставлено в один ряд с другими «модными» изобретенными традициями, например - шотландским килтом, так как именно мода в этом культурном контексте конструирует свой потенциал в деле конструирование идентичностей потому, что она «дает надежду и возможность приблизиться к идеалу. Она существует на границе тела, в пороговом пространстве между “я", осознаваемым изнутри собственного тела, и "не-я", наступающим извне. Двусмысленность границы между телом и одеждой стимулирует развитие моды, и не исключено, что именно в этом пороговом пространстве происходит взаимодействие между восприятием себя и попыткой выразить его посредством моды» (Боултвуд \& Джеррард, 2021), хотя в случае с культурными практиками Каджарской Персии, вероятно, более уместным констатировать не персонифицированные оппозиции, но противостояния различных подходов к визуализации телесности как компонента идентичности, которые могли быть ориентированы не только на внутреннее, но и внешнее потребление.

Во-вторых, появление такого феномена как «каджарское декольте» актуализировало гетерогенный характер иранского культурного пространства, которое начало в большей степени фрагментироваться на тренды высокой и низкой культуры, что, как следствие, привело к проявлению форм элитарной и массовой культуры, которые оперировали своими версиями визуализированной феминной телесности. Крис Хессельбайн, комментируя особенности современной историографической ситуации, полагает, что «во многих исследованиях, затрагивающих феномен телесного воплощения моды, тело рассматривалось скорее как неподвижная и бесчувственная болванка. В большинстве работ, посвященных взаимоотношениям одежды и тела, одежду описывают как поверхностный покров или как границу между телом и внешним миром» (Хессельбайн, 2019), хотя возможна и иная интерпретации и тела, и одежды, точнее - тактик и стратегий из визуализации, как процесса изобретения традиций, так и их продвижения в тех случаях, если отношения тела и одежды, например - «каджарское декольте», уже успели стать изобретенной культурной традицией как визуализации феминной телесности, так и моды в качестве обслуживающей ее культурной индустрии.

В-третьих, вероятно, без появления такой изобретенной традиции как «каджарское декольте» не были бы возможны или были бы содержательно иными другие, более поздние формы и попытки визуализации телесности как в рамках модернизационных культурных практик периода Пехлеви, так и радикальный отказ от них в рамках процессов традиционализации представлений о теле, вдохновленных Исламской революцией.

Вероятно, уже на этапе Каджаров в изображении женской телесности в Иране стали заметны первые элементы того, что уже при Пехлеви станет массовой культурой. Согласно российскому историку культуры И. Кондакову, для масскульта «во все культурные эпохи» характерен ограниченный набор 
функций, а именно - «общеинтересность содержания, доступность (клишированность, формульность) изложения, динамизм тематического развития, универсальность и простота жанров, увлекательность восприятия массовым реципиентом, установка на развлечение» (Кондаков, 2019, с. 6). Все эти особенности, в большей или меньшей степени, были характерны и для попыток визуализации женской телесности в период Каджаров. Вероятно, картины, где в качестве составного элемента фиксируемого феминного тела фигурирует «каджарское декольте», актуализируют именно такие качества массовой культуры как клишированность и формульность, но, вместе с тем, живопись эпохи Каджаров - это не классический масскульт, так как степень тиражирования и циркуляции подобной культурной продукции была еще недостаточной, чтобы описывать ее в категориях масскульта.

Если «каджарское декольте» никогда и не применялось в реальной моде как элемент женского платья и является плодом воображения персидских художников XIX века, то развитие фотографии, которое в Персии активно начинается к началу XX века, наоборот, фиксирует реальные культурные перемены (иллюстр. 13 - 16), которые имели место в восприятии женской телесности в позднекаджарском Иране, существенно влияя на ее визуализацию и фиксацию. Если мы обратимся к коллекции фотодокументов по истории Ирана периода Каджаров, которая хранится в Гарвардском Университете и оцифрована по его инициативе, то очевидны станут тенденции постепенной либерализации и, как следствие, легитимации феминной телесности не только в частных пространствах дома или его женской половины, но и в более широких социальных пределах общественной жизни.

\section{Феминная телесность в массовой культуре Ирана периода Пехлеви: либерализация, объективизация, сексуализация}

Период с 1925 по 1979 г., ознаменованный пребыванием у власти династии Пехлеви стал не только важным этапом в социальной, политической и культурной модернизации иранского общества, но и существенно изменил его отношение к телу, что стало следствием пересмотра государственной политики в отношении женщин. В научной и популярной литературе в отношении Ирана периода Пехлеви доминирует идея о том, что страна подверглась радикальному модернизационному эксперименту, к которому не была готова. Некоторые меры, предпринятые властями с 1925 по 1979 г., оказали существенное влияние на иранских женщин, хотя тенденции к эмансипации и, как результат, большего присутствия женщин в общественной жизни, а феминной телесности в культуре, были заметны и раньше, когда «в Иране, в конце 19 века, началось женское движение... женщины вышли на улицы во время конституционной революции; однако после революции их отправили обратно в свои дома, но обратно пошли далеко не все» (Esfandiari, 1997b), предпочтя активно бороться за собственные права и права других женщин в иранском обществе. 
Например, начиная с 1928 г. женщины получили возможность получать образование в Европе за счет государства. С 1935 г. женщинам было разрешено учиться в университетах Тегерана. В 1936 г. был введен запрет на ношение хиджаба, что, вероятно, отразило в иранских реалиях того времени «крайне высокомерное отношение к костюму народному, который изображается как система тривиальная, неразвитая и допотопная» (Васильева, 2017) со стороны элит, которые делали ставку на секуляризацию и модернизацию, а «народное» в реалиях Ирана ассоциировалось именно с мусульманским, которое элитами автоматически воспринималось как традиционное и поэтому антисовременное и автоматически - антиправительственное.

В 1944 г. в Иране было введено обязательное начальное образование для девочек. Кроме этого, после второй мировой войны женщины получили избирательные права и возможность избираться в парламент с 1963 г. В результате таких мер должности министров и судей были открыты в Иране для женщин (Esfandiari, 1997a). В 1966 г. в Тегеране была создана коалиция женских организаций Ирана, которая в качестве своей цели ставила борьбу за права женщин в достижении ими фактического равноправия с мужчинами. В 1967 г. в Иране был закон «О защите семьи», который стал одним из первых шагов в мусульманском мире в борьбе против семейного насилия. Кроме этого, возраст вступления в брак для женщин был повышен с 13 до 18 лет.

Такие прогрессивные мероприятия в отношении женщин в стране с мусульманским большинством не могли не отразиться и на их представленности, видимости и визуальности в культурных пространствах Ирана. На протяжении второго этапа в истории династии Пехлеви (после второй мировой войны) визуализация феминности в Иране имела несколько проявлений.

Во-первых, вестернизация общества, точнее - его политических, высших классов, привела к европеизации и / или американизации женской моды в той части иранского социума, которая формировала общество потребления, и основу идентичности которой составляла массовая или популярная культура.

Если «фемининность и телесность в своем сочетании занимают особое место в культуре постмодерна» (Новокшонова, 2020:35), то они, скорее всего универсальны, о чем свидетельствует появление региональных и национальных вариаций масс-культа в обществах потребления с ярко выраженной культурной и религиозной спецификой, в том числе - и в странах с численным доминированием мусульман, которые, как и западные формальные христиане (а фактически секуляризированные потребители), так же восприняли телесность и феминность в качестве центральных категорий масс-культа. Поэтому, во-вторых, начиная с 1950 - 1960-х гг. в Иране особое развитие получила местная национальная версия такого универсального сегмента массовой культуры общества потребления как женские журналы, которые воспроизводили те или иные визуальные дискурсы феминности, претендовавшие на статус культурного канона. По мнению некоторых исследователей совре- 
менного масс-культа, «в современной массовой культуре, наверное, нет более семантически универсального знака, чем обнаженное женское тело. Им иллюстрируют всё - от обложки нового бестселлера и журнальной рекламы духов, кофе и даже сантехники. Это - чистый лист, который можно заполнить любыми смыслами» (Ерьоменко, 2015). Вероятно, иранский поп- и масс-культ, проецируя на феминную телесность образы и стереотипы из западного культурного канона, имели в значительной степени вторичный и производный от западных образцов характер и в этой ситуации копировали американские / европейские тактики и стратегии визуализации женской телесности, воспроизводя их на страницах женских журналов.

В-третьих, Иран периода Пехлеви активно включился не только в процессы экономической, но и культурной глобализации и страна оказалась фактически открытой американским и европейским влияниям, которые проявились, в том числе, и в сфере проката в Иране западных фильмов, сопровождавшихся визуальной рекламой, актуализировавшей различные образы и проявления женской феминности. Что касается самих иранских фильмов ${ }^{1}$, то они были весьма радикальны в визуализации женского тела, в том числе - и обнаженного. В частности, в 1970 г. вышел фильм «Адам и Ева» (иллюстр. 17), где режиссёр почти буквально следовал библейскому тексту в визуализации одежды героини, точнее - ее отсутствия. Фильм «Монета удачи» (1970), хотя и не имел библейской основы, тоже не был принят блюстителями нравственности, так как героиня носила мини-юбку (иллюстр. 18).

Вероятно, в истории отношения к женскому телу и визуализированной феминности этого периода уместно провести параллель с предшествовавшим ему этапом пребывания у власти Каджаров. Если «каждарское декольте» было не более чем изобретенной традицией и элементом моды почти фантастического плана, что фактически исключало его реальное применение в качестве элемента женской одежды (иллюстр. 19 - 22) в частных и непубличных пространствах, то визуализация феминной телесности в период Пехливи частично стало продолжением и развитием культурных фантазий их каджарских предшественников с той только разницей, что феминная телесность в ее открытых и почти обнаженных проявлениях стала социально видимой и значимой для массовой культуры и общества потребления.

1 Автор статьи в этом разделе не анализирует подробно роль и место иранского кинематографа в процессах визуализации и фиксации феминной телесности в период пребывания у власти династии Пехлеви, так как полагает, что эта тема может стать предметом самостоятельного исследования. 


\section{Грудь Фернанды Лимы, которую не увидели иранские телезрители в 2013 году или женское тело между цензурированием и визуализацией в Исламской Республике Иран}

Революция 1979 г. положила конец более ранним практикам и стратегиям визуализации феминной телесности в целом и женского тела в частности, которые могут быть определены как имитация или трансплантация в иранские культурные контексты западного похода. По мнению ряда исследователей из иранской диаспоры (Silavi, 2019), и Пехлеви, и исламисты использовали женское тело как объект, содействуя его объективизации, т.е. фактическому подчинению, хотя модусы такой субординации до 1979 г. и после оказались радикально различными. Позиция иранских исламистов, которые пришли к власти в 1979 г., относительно женщин и проблем женской сексуальности отражена в текстах лидеров революции (Хомейни, 2011), хотя их больше заботили проблемы подчинения женщин и их интеграция в новую систему основанную на субординации и дискриминации в то время как проблемы гендера и сексуальности, репрезентативности феминности и телесности их интересовали только с точки зрения демонтажа влияния западной моды.

Если до 1979 г. женское тело было объективизировано в контекстах культурных предпочтений общества потребления, а «секс и женские тела использовались для получения прибыли» (Silavi, 2019), то исламизация иранского общества стимулировала иную объективизацию женского тела, актуализируя его неполноценность и подчиненность относительно мужского тела, что вытекало из политических предпочтений лидеров революции, но и в этой ситуации, по мнению некоторых авторов, хиджаб, ставший по настоянию исламистов, почти обязательным атрибутом женского тела в общественных пространствах «может быть слишком сексуальным» (Bucar, 2018). Несмотря на доминирование исламистской идеологии в современной Исламской Республике Иран (Bucar, 2017), представления различных поколений иранцев, мужчин и женщин, о женском теле в значительной степени могут не только отличаться (Sharifi, 2018), но в этой ситуации одновременного и параллельного сосуществования различных культурных трендов заметны и альтернативные тенденции в актуализации женских образов и визуализации феминной телесности, которые в наибольшей степени проявляются в иранском сегменте массовой культуры общества потребления.

«Многоаспектность тела, его способность совмещать личное и коллективное, природное и культурное» (Сироткина, 2021), которое органично вписывается в западные модели масс- и поп-культуры, в рамках исламизации было подчинено политическому проекту Ирана как исламской республики и поставлено на службу государственной машины, которая вынудила граждан позиционировать свои тела в соответствии с канонами ислама, который стал офици- 
альной идеологией республики. Если на официальном уровне предписан строгий дресс-код, который соотносится с нормами и канонами мусульманской моды и предписания ислама, предусматривая и допуская дискриминацию в отношении женщин, то альтернативные сегменты иранского общества предлагают иное восприятие телесности, хотя система воспроизводства официально санкционированной идентичности и лояльности ей, последовательно отвергает те версии телесности, которые не вписываются в официальный канон. «Архетип мусульманской женщины отягощен стереотипами, не всегда соответствующими реалиям» (Махлина, 2009), - полагает С. Махлина, комментируя особенности семиотики тела в западной и мусульманской культурной традициях. Поэтому, в рекламе женского нижнего белья в иранских интернет-магазинах можно видеть только само белье (но не моделей в белье), а если в рекламе присутствует женщина-модель, то тело подвергается цензуре и обнаженные участки зоны декольте, плеч и рук закрашиваются маркером (иллюстр. 38 - 39). Правда, некоторые интернетмагазины стремятся эти цензурные ограничения обойти и в рекламе нижнего белья фигурируют модели, но фотография в этом случае может практически не визуализировать обнаженные части тела, что, впрочем, не исключает определенной сексуализации образов женского тела. Другие интернет-магазины, наоборот, склонны следовать более агрессивным рекламным стратегиям, продвигая более откровенные и, как результат, порнифицированные, образы женской телесности (иллюстр. 40).

В отношении цензуры тела на телевидении иранские власти более последовательны и решительны. Например, в 2013 г. иранские телезрители не смогли в полной объеме посмотреть жеребьевку команд на Чемпионат мира по футболу, так как декольте ведущей мероприятия бразильской модели Фернанды Лимы (иллюстр. 35) не соответствовало допустимым в ИРИ нормам. При этом во внимание следует принимать и тот фактор, что в силу сохранения в Иране и при исламском режиме фактически капиталистической, рыночной, модели развития официальный канон постепенно размывается, так как сфера услуг, которая ориентирована на удовлетворение запросов потребителей, вынуждена актуализировать образы феминной телесности, делая это на грани официального и альтернативного дискурсов. Интернет-магазины Ирана, несмотря на наличие в стране исламистского режима, свободно предлагают продукцию, в той или степени актуализирующую и визуализирующую женскую телесность, что, например, относится к женскому белью и одежде (иллюстр. 36), хотя сами рекламные стратегии, актуализирующие телесность, в Иране отличны от западных аналогов (Демиденко, 2016). Поэтому в ряде случаев женское тело, как было уже показано выше, все же покрывается маркером или заштриховывается (иллюстр. 38 - 39), чтобы в той или иной степени соответствовать нормам и предписаниям ислама.

Официальные и альтернативные стратегии позиционирования феминной телесности в визуальных пространствах современного Ирана, вероятно, 
связаны с проблемами идентичности, точнее - ее визуализации, изобретения и воображения. Поэтому, вопрос «является ли идентичность проблемой, и если да, то насколько она универсальна» остается среди актуальных в современном мире, несмотря на то, что если даже мы согласны с тем, что «если идентичность является проблемой, то это проблема людей, которые хотят утвердить себя, но количество таких людей невелико» (Berikašvili, 2012). Это преимущественно теоретическое допущение относительно адекватно описывает проблемы визуализации феминной телесности в современных культурных средах Ирана, хотя число сторонников перемен в самом Иране, вероятно, незначительно, а государственная система стабильна в такой степени, что репрессируя сторонников эмансипации или вынуждая их эмигрировать, успешно воспроизводит официальный канон феминной телесности, сохраняя монополию (не столь монолитную, как в 1980-е гг. и поэтому периодически оспариваемую) на такие практики в общественных и культурных пространствах.

Альтернативный способ визуального восприятия женской телесности в современном Иране представлен в порно, несмотря на его запрет в Исламской Республике 1 . В ряде случаев инициаторами визуализации альтернативной точки зрения на женскую телесность в Иране становятся сами модели. Сложно судить, в какой степени иранские модели знакомы с теоретическими работами по семиотике, но они, подобно ее наиболее ортодоксальным сторонникам, стремятся воспринимать мир как «художественное пространство», интерпретируемое ими при помощи феминной телесности как «запись результатов эстетического созерцания пространства, представленных в виде определенного художественного контента» (Andriadze, 2011), хотя последний в ряде случаев более чем альтернативен, что ведет к конфронтации с официальным каноном, основанным на содержательно иных концепциях визуализации женского тела и, тем более, его представленности в культурных и общественных пространствах.

В 2016 г. в Иране было арестовано несколько моделей (иллюстр. 33 - 34), которые были осуждены и приговорены к тюремному заключению до шести лет по обвинению в «распространении проституции и культуры обнаженного тела в западном стиле» (Robinson, 2016). В 2017 г. одна из иранских моделей, известная как Неггзия (иллюстр. 28 - 29), приняла участие в фотосессии в нижнем белье, признанной властями ИРИ антиисламской и аморальной, что вынудило ее бежать во Францию (Knox, 2019), хотя еще раньше, в 2012 г., в Ютьюбе оказался доступен ролик, снятый девушками иранского происхождения, живущими в Европе, на котором они позировали топлес, позицио-

1 Автор в данной статье не анализирует особенности визуализации женской феминности в иранском порнодискурсе современной массовой культуры, так как порно в ИРИ находится под запретом, а сама проблематика порнодискурса в мусульманском обществе в некоторой степени маргинальна, что делает ее в большей степени пригодной для изучения в рамках не штудий телесности, но фронтирных исследований или культурной антропологии. 
нирую фотосессию как протест против «порнификации женщин в Иране, где они низведены до уровня объектов» (Iranian women... 2012). В том же 2017 г. Гольшифте Фарахани (иллюстр. 30 - 32) французская актриса иранского происхождения также стала героиней ряда фотографий, которые в ИРИ были признаны аморальными (Memarian, 2017).

Другой визуальный дискурс альтернативного женского тела представлен преимущественно в виртуальном пространстве, в частности - в инстраграмканале «Rich Kids of Tehran» (иллюстр. 26 - 27), размещенные в котором фотографии серийны и неуникальны в том плане, что содержательно, тематически и сюжетно они практически неотличимы от аналогичных фотографий, размещенных в российских (ВКонтакте) и западных (Фэйсбук) социальных сетях, что свидетельствует об унификации представлений об идеальном теле в обществе потребления. Инстраграм-канал «Rich Kids of Tehran» фактически подчеркивает, что «модный дизайн составляет основу создания образа современного человека и что существуют области моды, где конфликт между современным и несовременным человеком выходит на поверхность, вскрывая стереотипный, эстетический и расово окрашенный образ современного человека; он также выявляет (всегдашнюю) экзотику несовременного» (Баласеску, 2019), склонного, например - в иранском случае, следовать ограничивающим предписаниям государственно санкционированной моды, основанной на воспроизводстве исламистского дискурса.

Различные образы женской телесности активно используются для продвижения товаров (иллюстр. 37), получивших широкое распространение в обществе потребления, в частности - в молодежной одежде (иллюстр. 23 - 25). Например, современная молодежная мода Ирана не только актуализирует феминные образы, но и непосредственно при их визуализации апеллирует к историческому и культурном наследию Каджаров, что нашло свое отражение в линии одежды Qajar Woman T-Shirts, между предметами которой и отдельными памятниками каджарской живописи заметна определенная преемственность сюжетного и тематического плана. В частности, среди центральных мотивов такой молодежной одежды - образы женщин, одновременно генетически уходящие к героиням иранской живописи периода Каджаров и обыгрывающие стереотипные образы массовой культуры.

\section{От секса к порно: противоречия визуализации женской телесности в Иране}

Современный Иран несмотря на явные особенности политического режима и воспроизводимые им культурные барьеры и цензурные ограничения в той или иной степени принимает участие в процессах глобализации, что привело к трансплантации в иранские культурные пространства определенных элементов массовой культуры общества потребления, которые различ- 
ными способами содействуют актуализации или большей визуализации в общественных пространствах феминной телесности.

Иранская массовая культура в определенной степени повторяет, имитирует или симулирует, проявления западной, но в полной мере их не повторяет и не воспроизводит. Поэтому иранский масскульт избежал таких явлений как порно-шок и порно-шик, а порно-дискурс в культурные пространства общества потребления был перенесен и трансплантирован уже в готовом виде по мере развития современных коммуникационных технологий, в первую очередь - Интернета. Новые поколения молодых иранцев активны в использовании социальных сетей и других возможностей современного глобального информационного общества, а религиозные предписания, запреты и ограничения, в том числе - в сфере одежды и накладываемых ей ограничений в визуализации телесности, кажутся им более чем излишними.

Вместе с тем визуализация тела и сексуализация телесности в современном Иране в его общественных и культурных пространствах представлена в гораздо меньшей степени, чем это имеет место в современной западной культуре. Комментарий в одном из анонимных интервью подчеркивает, что иранцы «абсолютно необразованы в сексуальном смысле. Просто вынимают ту часть тела, которая предназначена для сотворения детей. Они смотрят секс-фильмы или иногда найдут какую-нибудь статью по теме, но большинство черпает информацию из порно... многие женщины здесь не знают, что такое оргазм или просто не получают достаточно удовольствия... я считаю мужчин очень эгоистичными, это правда... После секса иранцы одеваются, идут в туалет или душ, потом ложатся спать. Никаких поцелуев или объятий. Как будто они просто справляют нужду. Именно поэтому я выбираю мастурбацию» (Leymarie, 2018).

В этой ситуации иранцы обращаются к тем формам и проявлениям современной массовой культуры, которые, с точки зрения, традиционно и консервативно настроенной части иранского общества могут восприниматься как нежелательные или даже недопустимые. Известно, что при определенных манипуляциях с настройками безопасности браузера не представляет труда не только обойти цензурные ограничения, но и получить доступ на крупнейшие сайты соответствующей направленности, где можно найти и классифицировать контент, определяемый или позиционируемый его создателями или администраторами сайтов как «иранский», хотя в ряде случаев иранское происхождение контента может оспариваться.

В ряде случаев маска, скрывающая лицо участницы таких роликов, может указывать на действительно иранское происхождение контента, так как производство и распространение порно в ИРИ является уголовно наказуемым преступлением как для создателей, так и актеров такой видеопродукции. Тем не менее, в рамках иранского порно-дискурса возникла радикальная попытка визуализации и актуализации не просто феминной телесности, но обнаженной, порнографической или порнофицированной, версии женского 
тела. Порно-ролики, позиционируемые как иранские, призваны играть роль культурного и социального провокатора. Актрисы, согласно требованиям жанра и в соответствии с нормами порнографического канона, конечно, обнажены, но некоторые демонстративно снимаются в платке, столь усердно навязываемом исламистским режимом иранским женщинам. Другие имеют тату в форме цветов иранского флага, что может восприниматься как оскорбление государственной символики ИРИ, а диалоги и описание роликов на фарси не оставляет сомнений в их иранском происхождении.

С точки зрения официальной культурной модели, которая доминирует в ИРИ, такой контент массовой культуры современного иранского общества является маргинальным, но его появление и развитие, как минимум, указывает на рост тенденций фрагментации современного культурного пространства Ирана и фактически одновременное сосуществования различных форм восприятия феминной телесности, основанной на ее отрицании и сокрытии в рамках официального канона или, наоборот, максимальной открытости, сексуализации и порнификации в контекстах альтернативных культурных стратегий.

\section{Выводы}

Подводя итоги статьи, во внимание следует принимать ряд факторов, которые в значительной степени повлияли как на формы, так и на особенности фиксации и актуализации феминного тела в дискурсе иранской культуры от эпохи Каджаров до процессов исламизации социальной и культурной жизни в результате победы в 1979 году Исламской революции.

Во-первых, визуальное искусство периода правления Каджаров стало одной из первых модерных иранских изобретенных традиций, вдохновленных началом процессов модернизации, которые в Персии не только обладали значительной спецификой, но и отличались более медленными темпами культурных и социальных изменений в жизни общества. История каджарской живописи обеспечивает ее историков с несколькими примерами работ, которые фиксируют и визуализирую не только различные социальные и культурные роли феминного тела, но и отражают такую его особенность как «каджарское декольте».

Само «каджарское декольте», вероятно, никогда не использовалось в реальной одежде и представляет собой плод фантазии персидских художников, но само его появление на живописных полотнах, как минимум, свидетельствует об одновременном взаимодействии целого ряда культурных и социальных тенденций.

Первой тенденцией стала европеизация культурного дискурса, так как без внешнего стимула появление женщины как тела в качестве героя картин в стране с преобладанием шиитов было бы маловероятным. Второй тенденцией стала секуляризация, так как легкая эротизация объекта, которая грани- 
чила с его порнофикацией, указывала на начало эрозии преимущественно религиозного сознания. Третья тенденция была представлена качественно и содержательно новой фрагментацией иранской культуры на «высокую» и «низкую», что в перспективе вело к генезису на их базе массовой и популярной культур с их изобретенными традициями. В этом контексте, вероятно, не существовавшее в реальности «каджарское декольте» стало одной из первых изобретенных традиций раннего модернизирующего Ирана, предназначенной для реализации и удовлетворения запроса культурных потребностей носителей «высокой культуры», хотя последняя к тому времени начинает постепенно подвергаться эрозии.

Во-вторых, процессы эрозии преимущественно религиозного канона отношения к феминной телесности, которые начали при Каджарах, получили свое продолжение в период пребывания у власти династии Пехлеви.

Если Каджары предпринимали лишь робкие и непоследовательные попытки модернизации, то Пехлеви инициировали радикальный модернизационный эксперимент, который одновременно предусматривал и секуляризацию, и вестернизацию. Эти тенденции существенно повлияли на проявление телесности в визуальном дискурсе Ирана 1920 - 1970-х гг., когда феминная телесность не только не подавлялась и не маргинализировалась, но ее актуализация и визуализация вошли в число основных культурных трендов. Визуальные образцы и проявления иранской феминной телесности 1950 - 1970-х гг. в контекстах моды и степени обнаженности женского тела не только игнорируют шиитские основы традиционной версии иранской идентичности, но в значительной степени интегрированы в привнесенный западный канон общества потребления, успешно имитируют его и практически от него неотличимы.

В-третьих, Исламская революция 1979 г. самым радикальным образом изменила векторы и траектории проявления и визуализации феминной телесности в Иране, фактически маргинализировав женское тело, лишив его статуса культурного и рекламного объекта, заключив в пространства исламской моды.

В истории тела в период после Исламской революции, вероятно, следует выделять два этапа. На первом этапе (1980-е гг.) новые политические элиты взяли решительный курс на архаизацию культурной жизни и исламизацию визуального искусства, что вело к автоматической и неминуемой маргинализации целых пластов иранского искусства прошлого, которые было невозможно интегрировать в новый исламистский канон. На втором этапе, который начался в 1990-е годы и был связан в появлением иранской версии общества потребления и массовой культуры официальная риторика в отношении неприятия визуализированной телесности хотя и сохранялась, но виртуализация поставила под сомнение государственную монополию на контроль относительно тела и его позиционирования. Поэтому на современном этапе феминная визуализированная телесность в Иране существует как дихотомия государственно поддерживаемого и контролируемого дискурса (государ- 
ственная служба, официальная культура, строгий дресс-код для женщин, доминирования исламской моды), основанного не неприятии женского тела как предмета изображения при условии дальнейшего тиражирования, и его альтернативы, представленной социальными сетями, фактически актуализирующими и визуализирующими женскую телесность в формах, конфликтующих с предписаниями исламской моды.

В целом, феминная телесность стала компонентом истории иранского визуального искусства и несмотря на ее маргинализацию в условиях исламизации общества на современном этапе мигрировала в виртуальные пространства социальных сетей и Интернета, где продолжает актуализироваться отдельными пользователями. Визуальные образы феминной телесности современной иранской культуры развиваются как гетерогенные, будучи представленными официальными, интегрированными в канон исламской моды, и альтернативными, которые актуализируют культурную и историческую преемственность с более ранними тактиками и стратегиями визуализации женского тела от «каджарского декольте» до эмансипированной феминности периода Пехлеви.

Тем не менее, и «каджарское декольте», и эмансипированная феминность 1950 - 1970-х гг., и маргинализированная женская телесная феминность на официальном уровне Исламской Республики 1980 - 1990-х гг. стали изобретенными традициями как социальной и культурной, так и «женской» истории Ирана, которые нуждаются в дальнейшем междисциплинарном изучении в контекстах культуральной и интеллектуальной истории, археологии и историй идей, а также исследований телесности в контекстах социальной, культурной и исторической антропологии с образением как к нарративным, так и визуальным источникам.

\section{Список иллюстраций}

Иллюстр. 1 - 2. Богиня со змеями (малая) и Богиня со змеями (большая). Археологический Музей, Ираклион. Источник: Богиня со змеяли (малая). Археологический Музей, Ираклион. Retrieved from https://ru.wikipedia.org/wiki/Богиня_со_змеями

Иллюстр. 3 - 4. Реконструкции «Богинь со змеями». Археологический Музей, Ираклион. Источник: История моды. Молодая персидская дама "в европейском вкусе" и Богини Kpuma. Retrieved from https://gorbutovich.livejournal.com/40343.html

Иллюстр. 5. Неизвестный художник. Женщина у окна. Иран, XIX в. Холст, масло. Источник: Искусство Ирана в Музее Востока: виртуальная экскурсия по выставке. Retrieved from https://magazineart.art/online/iskusstvo-irana-v-muzee-vostoka-virtualnaja-jekskursija-po-vystavke/

Иллюстр. 6. Неизвестный художник. «Женщина у окна». Иран. XIX век. Государственный музей Востока. Источник: Багдасарова, С. (2021, 17 мая). Каджары: декадентская роскошь в Музее Востока. In The Art Newspaper Russia. Retrieved from http://www.theartnewspaper.ru/posts/9070/ 
Иллюстр. 7. Неизвестный художник. «Женщина у окна». Иран. XIX век. Государственный музей Востока. Источник: Багдасарова, С. (2021, 15 мая). Выставка гаремных красавицперсиянок. В Музее Востока показывают яркое искусство эпохи Каджаров. In Шакко: об искусстве. Retrieved from https://zen.yandex.ru/media/shakko/vystavka-garemnyhkrasavicpersiianok-609f805b46cbf11541f0499e

Иллюстр. 8. Женщина с розой. Холст, масло. 184x94 см. Первая четверть ХIX в. Государственный Эрмитаж. Источник: Гасанова, Н. (2018, 18 апреля). Искусство Ирана. Каджарская живопись (конец XVIII - XIX вв.). In Искусство. Retrieved from https://obiskusstve.com/ 1401420391620807307/iskusstvo-irana-kadzharskaya-zhivopis-konets-xviii---xix-vv/

Иллюстр. 9. Женщина с диадемой. Холст, масло, клеевые краски. 150x89 см. Середина XIX в. Государственный Эрмитаж. Источник: Гасанова, Н. (2018, 18 апреля). Искусство Ирана. Каджарская живопись (конец XVIII - XIX вв.). In Искусство. Retrieved from https:// obiskusstve.com/1401420391620807307/iskusstvo-irana-kadzharskaya-zhivopis-konetsxviii---xix-vv/

Иллюстр. 10. Женщина с шарфом. Холст, масло, клеевые краски. 145x85 см. Середина XIX в. Государственный Эрмитаж. Источник: Гасанова, Н. (2018, 18 апреля). Искусство Ирана. Каджарская живопись (конец XVIII - XIX вв.). In Искусство. Retrieved from https:// obiskusstve.com/1401420391620807307/iskusstvo-irana-kadzharskaya-zhivopis-konets$\underline{\text { xviii---xix-vv/ }}$

Иллюстр. 11. Неизвестный художник. Портрет женщины в платье. Холст, масло (деревянная рама); 152 X78 см. XIX в. Источник: Гасанова, Н. (2018, 18 апреля). Искусство Ирана. Каджарская живопись (конец XVIII - XIX вв.). In Искусство. Retrieved from https:// obiskusstve.com/1401420391620807307/iskusstvo-irana-kadzharskaya-zhivopis-konetsxviii---xix-vv/

Иллюстр. 12. Сцена из притчи о шейхе Сан'ане» из поэмы автора конца XI - начала XII века Фарид ад-Дина Аттара «Язык птиц». Папье-маше. Роспись под лаком. Источник: Искусство Ирана в Музее Востока: виртуальная экскурсия по выставке. Retrieved from https://magazineart.art/online/iskusstvo-irana-v-muzee-vostoka-virtualnaja-jekskursijapo-vystavke/

Иллюстр. 13. Захра Султан. Дочь Майме Ханум, уважающая шариат. Источник: Zahrā soltān. In aks dar safhe-ye 296 älbom-ast. Doxtar-e meh-e Meh-e Xānom, ehterām-e šaria. Retrieved from http://www.qajarwomen.org/fa/items/1257A77.html (на фарси)

Иллюстр. 14. Женщина. Источник: Yek zan. In aks dar safhe-ye 296 älbom-ast. Retrieved from http://www.qajarwomen.org/fa/items/1257A78.html (на фарси)

Иллюстр. 15. Женщина, сидящая у деревьев. Источник: Xānomi nešaste kenār-e deraxtān. In aks motealleq be majmue-ye akshā-yi-st ke Abdollāh-e mirzā hamsar-e nozhat gerefte-vo yā dar barx-i akshā ke xod hozur dārad durbin rā be šaxs-e digar-i dāde-ast. Retrieved from http:// www.qajarwomen.org/fa/items/1140A90.html (на фарси)

Иллюстр. 16. Шоку Азми и Хома Пирния. Источник: Šekve-ye azmi-yo Homā Pirniyā. Cap: šekve-ye azm-i, rāst: Homā Pirniyā, doxtar-e mirzā hosn-e Xān-e Moširoddowle Pirniyā. Aks dar emārate andaruni lālezār motealleq be mirzā Amir-ad Daul Xān gerefte šode. Retrieved from http:// www.qajarwomen.org/fa/items/1258A28.html (на фарси)

Иллюстр. 17. Постер иранского фильма «Адам и Ева», 1970. Источник: Film-e «Ādam o Havvā» (1349). Retrieved from https://filme-farsi.blogspot.com/2018/08/1349 9.html (на фарси)

Иллюстр. 18. Кадр из фильма «Монета удачи», 1970. Источник: Film-e «Sekke-ye šāns» (1349). Retrieved from https://filme-farsi.blogspot.com/2019/06/1349 13.html (на фарси) 
Иллюстр. 19 - 22. Обложки иранских женских журналов 1970-х гг. Источник: А ведъ еще 40 лет назад Иран был таким. Retrieved from https://bigpicture.ru/a-ved-eshhe-40-let-nazadiran-byl-takim/

Иллюстр. 23. Qajar Woman by Shakira Preimum T-Shirt. Источник: Qajar Woman by Shakira Preimum T-Shirt. Retrieved from https://pixels.com/featured/qajar-woman-by-shakiba-gl6salma.html?product=adult-tshirt

Иллюстр. 24. Persian Inspired T-Shirt. Источник: Pin on Persian Inspired T-Shirts. Retrieved from https://www.pinterest.ru/pin/252342385358980160/

Иллюстр. 25. Persian Qajar Princess - We Can Do It Premium T-Shirt. Источник: Persian Qajar Princess - We Can Do It Premium T-Shirt. Retrieved from https://www.amazon.com/PersianQajar-Princess-Premium-T-Shirt/dp/B08HF8WVMK

Иллюстр. 26 - 27. Фотографии, размещенные в инстраграм-канале «Rich Kids of Tehran». Источник: Золотая молодёжь Ирана на отдыхе. Retrieved from https://cameralabs.org/ 9831-zolotaya-molodjozh-irana-na-otdykhe

Иллюстр. 28 - 29. Фотографии иранской модели известной как Негзия, опубликованные в 2017 г. западными СМИ и ставшие причиной ее эмиграции из Ирана. Источник: Knox, P. (2019, July 5). 'No respect for women': Iranian model forced to flee her home country as she faced public lashing for half-naked photoshoot. In The Sun. Retrieved from https://www.thesun.co.uk/news/9442855/iranian-model-homeless-paris-asylum-lashed-half-naked-photos/; Лекомцева, Н. (2019, 6 июля). Иранской модели пришлось бежать из страны после снимков в белье. In Cosmopolitan. Retrieved from https://www.cosmo.ru/lifestyle/news/ 06-07-2019/iranskoy-modeli-prishlos-bezhat-iz-strany-posle-snimkov-v-bele/

Иллюстр. 30 - 32. Гольшифте Фарахани - французская актриса иранского происхождения. Источник: Hot Golshifteh Farahani Photos Are So Damn Hot That You Can't Hold Them. Retrieved from https://6b33.net/49-hot-golshifteh-farahani-photos-are-so-damn-hot-thatyou-cant-hold-them/

Иллюстр. 33 - 34. Нилофар Бехбуди и Эльхам Араб - иранские модели, осужденные в ИРИ в 2016 г. Источник: Robinson, J. (2016, December 7). Twelve fashion bloggers and social media models are jailed in Iran for 'spreading prostitution and a Western-style culture of nudity'. In Daily Mail. Retrieved from https://www.dailymail.co.uk/news/article-4008684/Twelvefashion-bloggers-social-media-models-jailed-Iran-spreading-prostitution-Western-styleculture-nudity.html

Иллюстр. 35. Бразильская модель Фернанда Лима на церемонии жеребьевки команд-участниц ФИФА 2014 г. Источник: Декольте Фернанды Лимы испортило иранским болельщикам жеребьевку ЧМ-2014. In НTВ, 2013, 12 декабря. Retrieved from https://www.ntv.ru/ novosti/773656

Иллюстр. 36. Реклама женского белья в Иране в условиях цензурных ограничений. Источник: Kānāl-e lebās-e zir , xarid-e lebās-e zir zanāne, kānāl-e xarid-e lebās-e zir zanāne dar telgerām, forušgāh-e lebās-e zir zanāne (Канал Lingerie, Buy Lingerie, канал о покупках ниюнего белья в Telegram, магазин нижнего белья). Retrieved from http://www.samteto.ir/ (на фарси)

Иллюстр. 37. Готовая выкройка платья с макси-декольте. Источник: Olgu-ye āmāde-ye lebās māksi dekolte (Готовая выкройка платья с макси-декольте). Retrieved from https://honarpars.com/shop/product// (на фарси)

Иллюстр. 38 - 39. Примеры цензурирования женского тела в современных интернет-магазинах Ирана. Источник: Paniz lingerie. Retrieved from https://panizwear.com/pages/70/ (на фарси); Set-e lebās-e fāntezi dāman-i jurāb-e dār-e model-e 2020 (Нарядный колплект с 
юбкой и чулками 2020 г.). Retrieved from https://lebaskhab.com/product/fantasy-setdress-skirt-with-sock-model-2020/ (на фарси)

Иллюстр. 40. Реклама одного из интернет-магазинов нижнего белья в Иране. Источник: Gāleriуе äntik... 2021 (Антикварная галлерея... 2021). Retrieved from https://www.facebook.com/ 146696625475439 (на фарси)
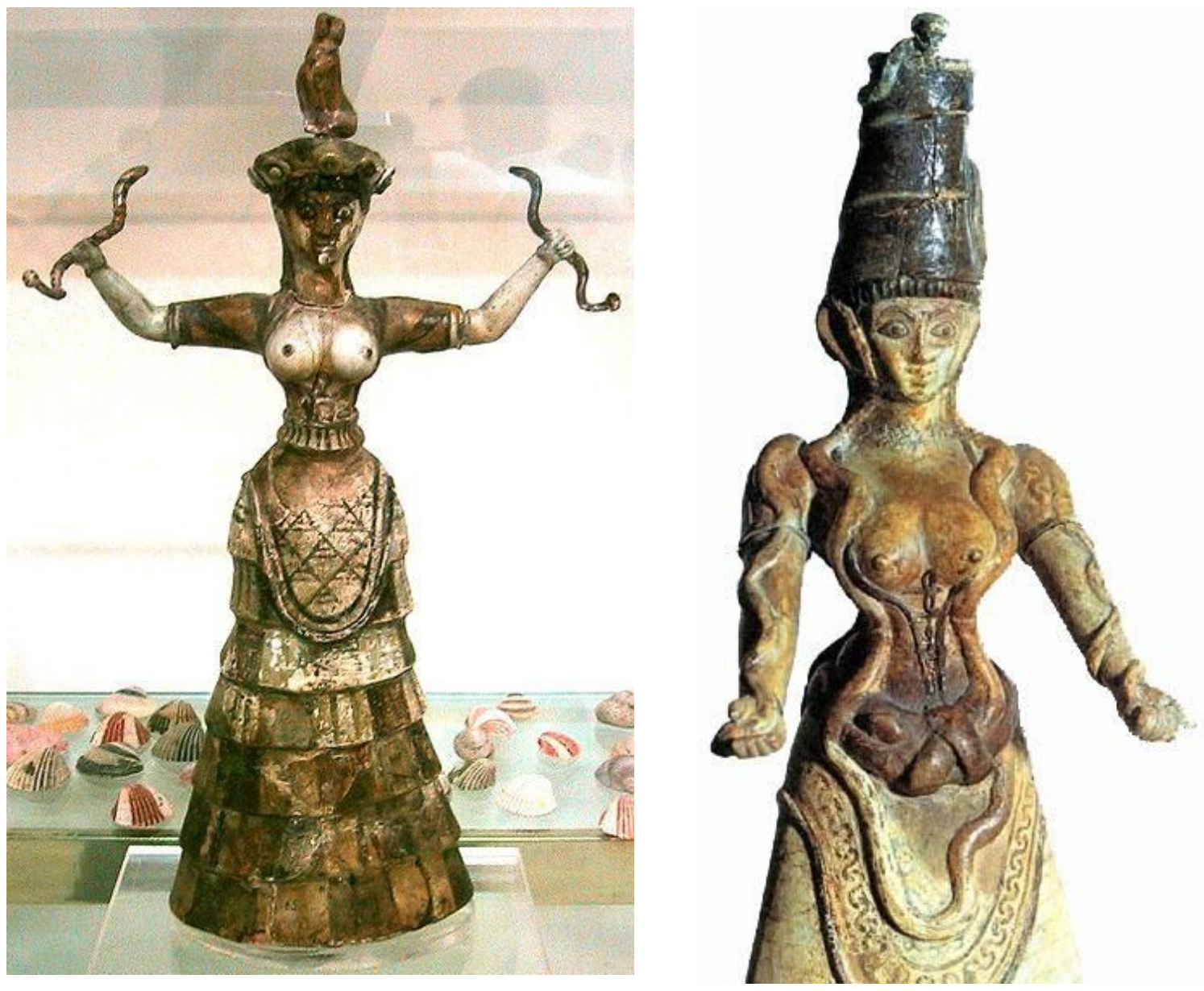

Иллюстр. 1 - 2. Богиня со змеями (малая) и Богиня со змеями (большая). Археологический Музей, Ираклион

Figs. 1 - 2. Goddess with Snakes (small) and Goddess with Snakes (large). Archaeological Museum, Heraklion 

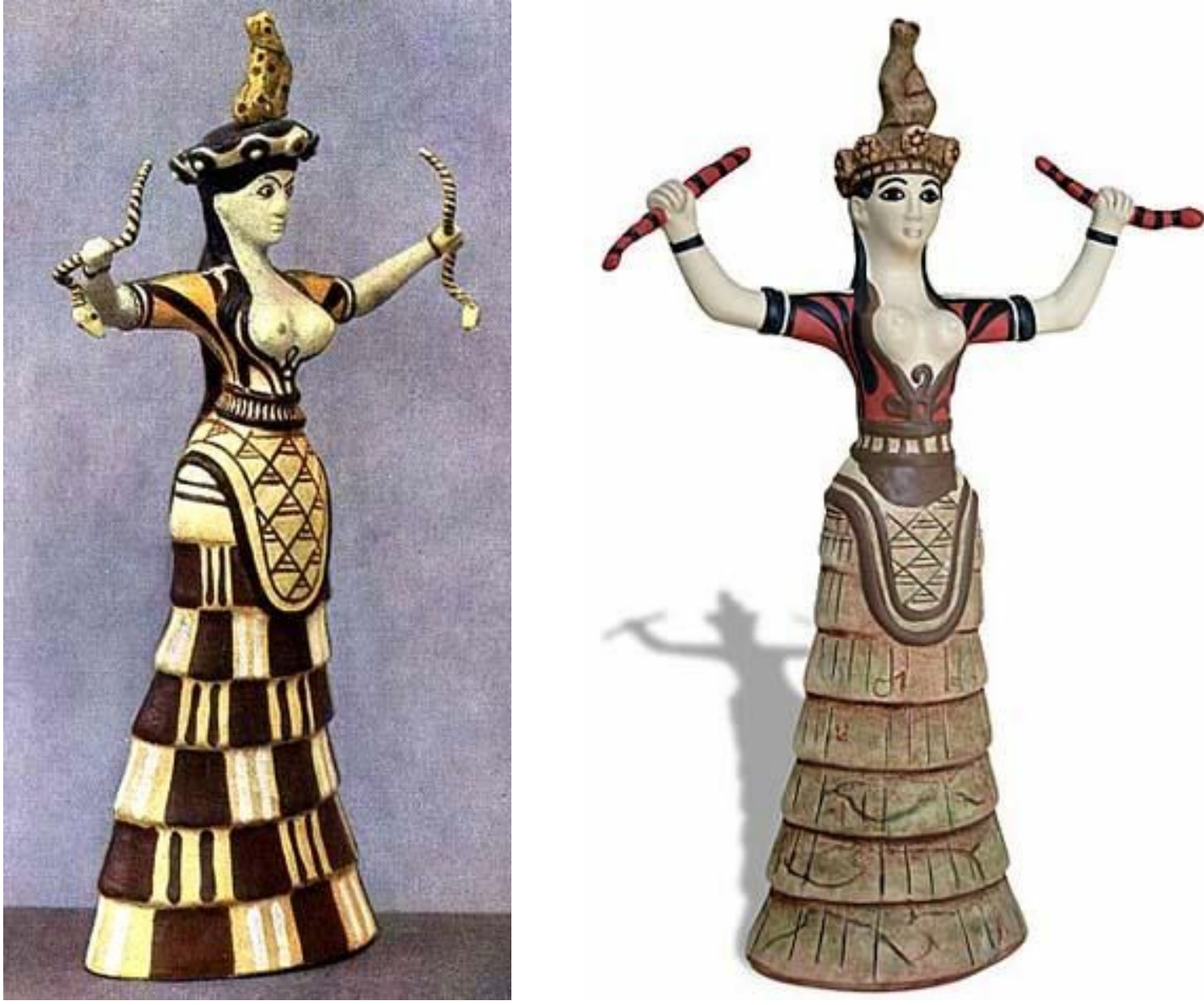

Иллюстр. 3 - 4. Реконструкции «Богинь со змеями»

Figs. 3 - 4. Reconstructions of the "Goddesses with Snakes" 

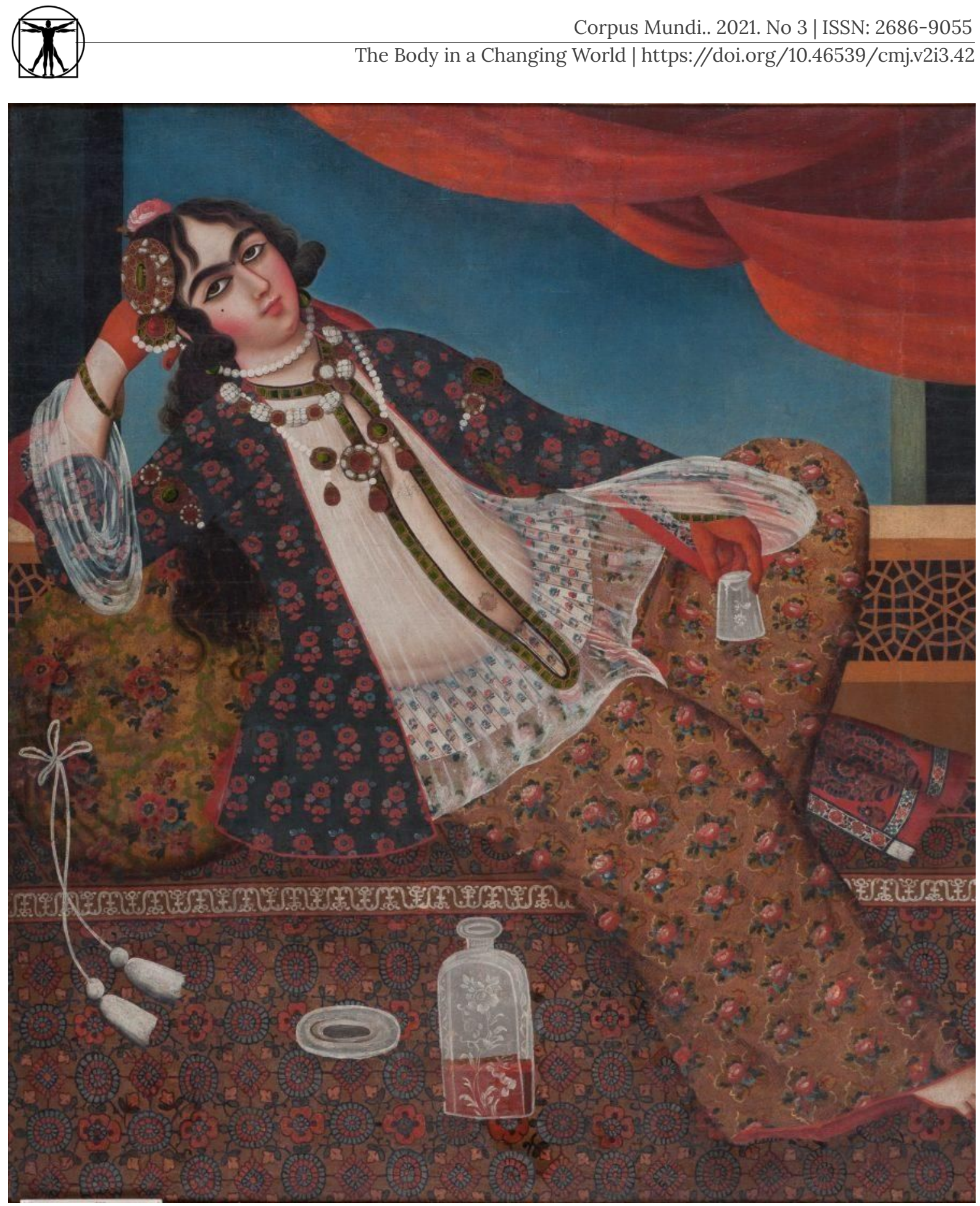

Иллюстр. 5. Неизвестный художник. Женщина у окна. Иран, XIX в. Холст, масло.

Пример иранской живописи 19 века, одновременно визуализирующий как феминное тело, так и особенности персидской моды.

Figs. 5. Unknown artist. Woman at the Window. Iran, 19th century. canvas, oil.

An example of 19th century Iranian painting, simultaneously visualizing both the feminine body and the peculiarities of Persian fashion. 


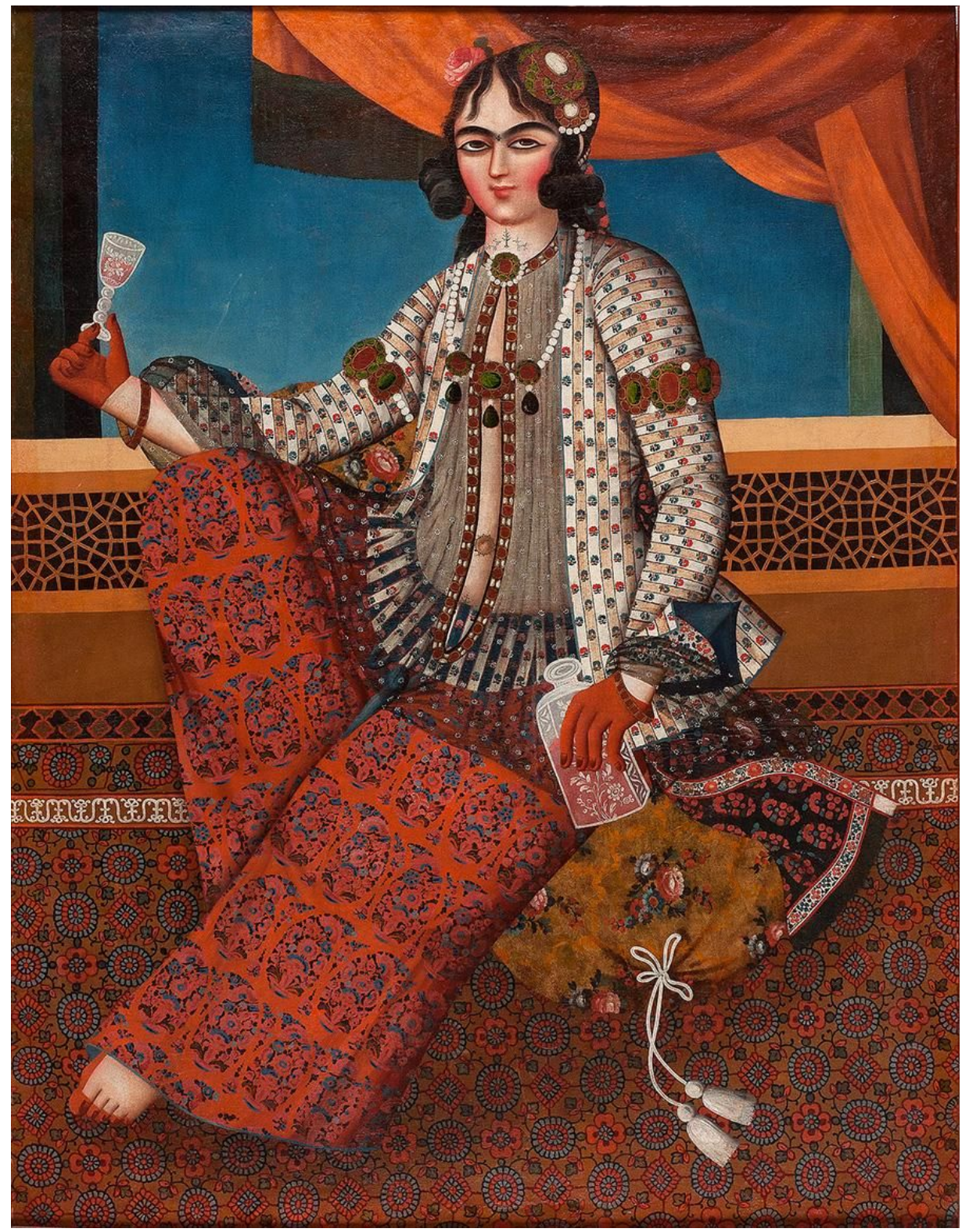

Иллюстр. 6. Неизвестный художник. «Женщина у окна». Иран. XIX век. Государственный музей Востока.

Картина минимально фиксирует обнаженную женскую феминность, в значительной степени отражая особенности моды и стиля, а также допустимость употребления алкоголя в мусульманском обществе. Женщина держит в руках не только рюмку, но и уже неполную бутылку.

Figs. 6. Unknown artist. "Woman at the Window. Iran. 19th century. State Museum of the Orient.

The painting records minimally naked female femininity, largely reflecting the peculiarities of fashion and style as well as the permissibility of alcohol consumption in Muslim society. The woman is holding not only a shot glass, but also an already incomplete bottle. 


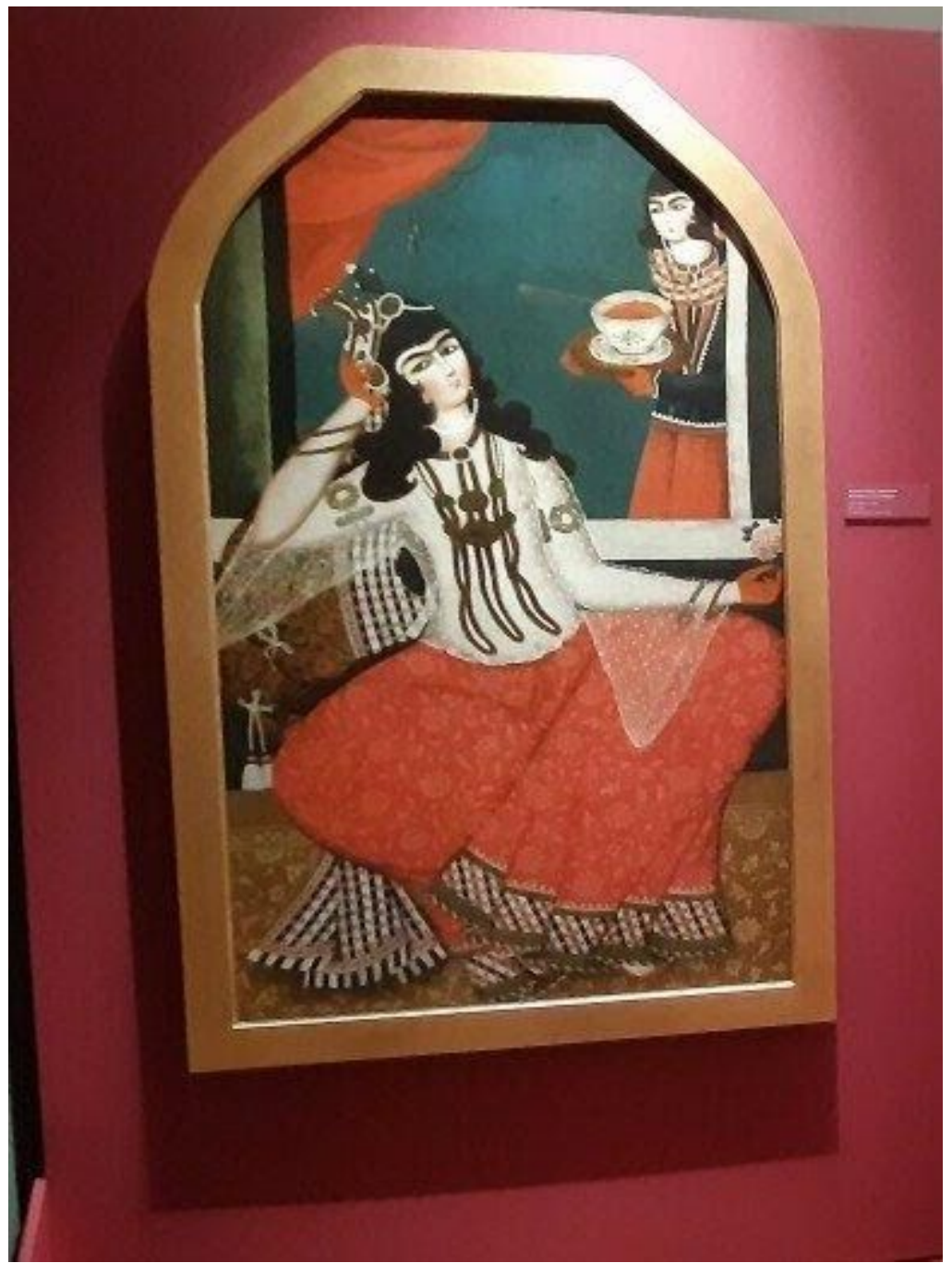

Иллюстр. 7. Неизвестный художник. «Женщина у окна». Иран. XIX век. Государственный музей Востока.

Несмотря на то, что картина не фиксируют обнаженные проявления феминной телесности, она отражает особенности моды Ирана 19 столетия, так как представляет классический набор элементов женского стиля, включая украшения головного убора (эгет), тонкую рубаху (пирохан), наплечные (браслеты базубанды) и пышные цветные штаны (шальвары).

Figs. 7. Unknown artist. "Woman at the Window. Iran. 19th century. State Museum of the Orient.

Although the painting does not record nude manifestations of feminine corporeality, it reflects features of 19th-century Iranian fashion, as it presents a classical set of feminine style elements, including headdress jewelry (eget), a thin shirt (pirohan), shoulder-length (bazubandi bracelets) and puffed colored pants (shalvars). 


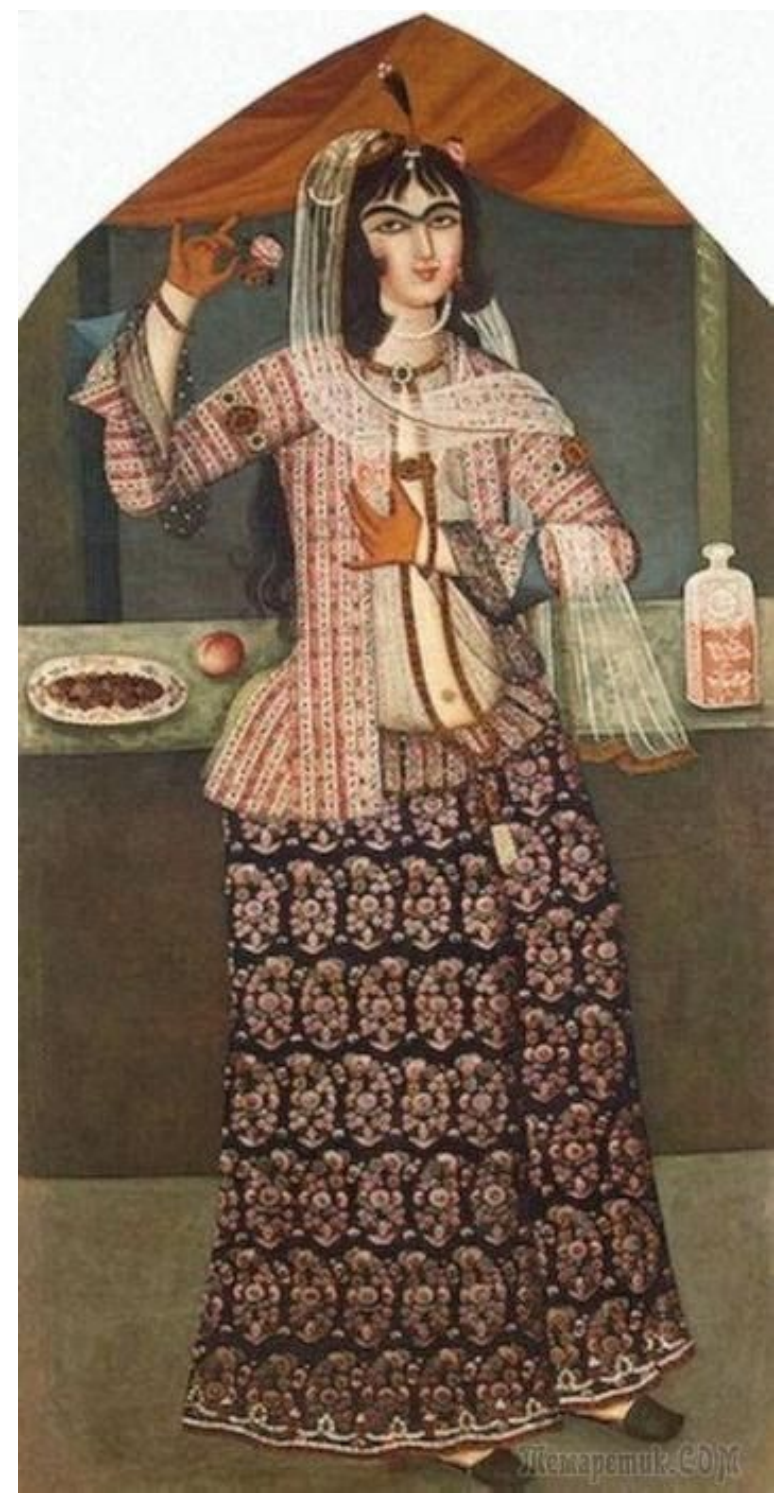

Иллюстр. 8. Женщина с розой. Холст, масло. 184х94 см. Первая четверть XIX в. Государственный Эрмитаж.

Картина демонстрирует относительный баланс в визуализации женского тела, отражая как обнаженную феминность (вырез), так и и традиционные атрибуты женского костюма как составные элементы моды первой половины 19 века.

Figs. 8. Woman with a Rose. Canvas, oil. $184 \times 94 \mathrm{~cm}$. First quarter of the 19th century. State Hermitage.

The painting demonstrates a relative balance in rendering the female body, reflecting both the naked femininity (neckline) and the traditional attributes of female costume as constituent elements of fashion of the first half of the 19th century. 


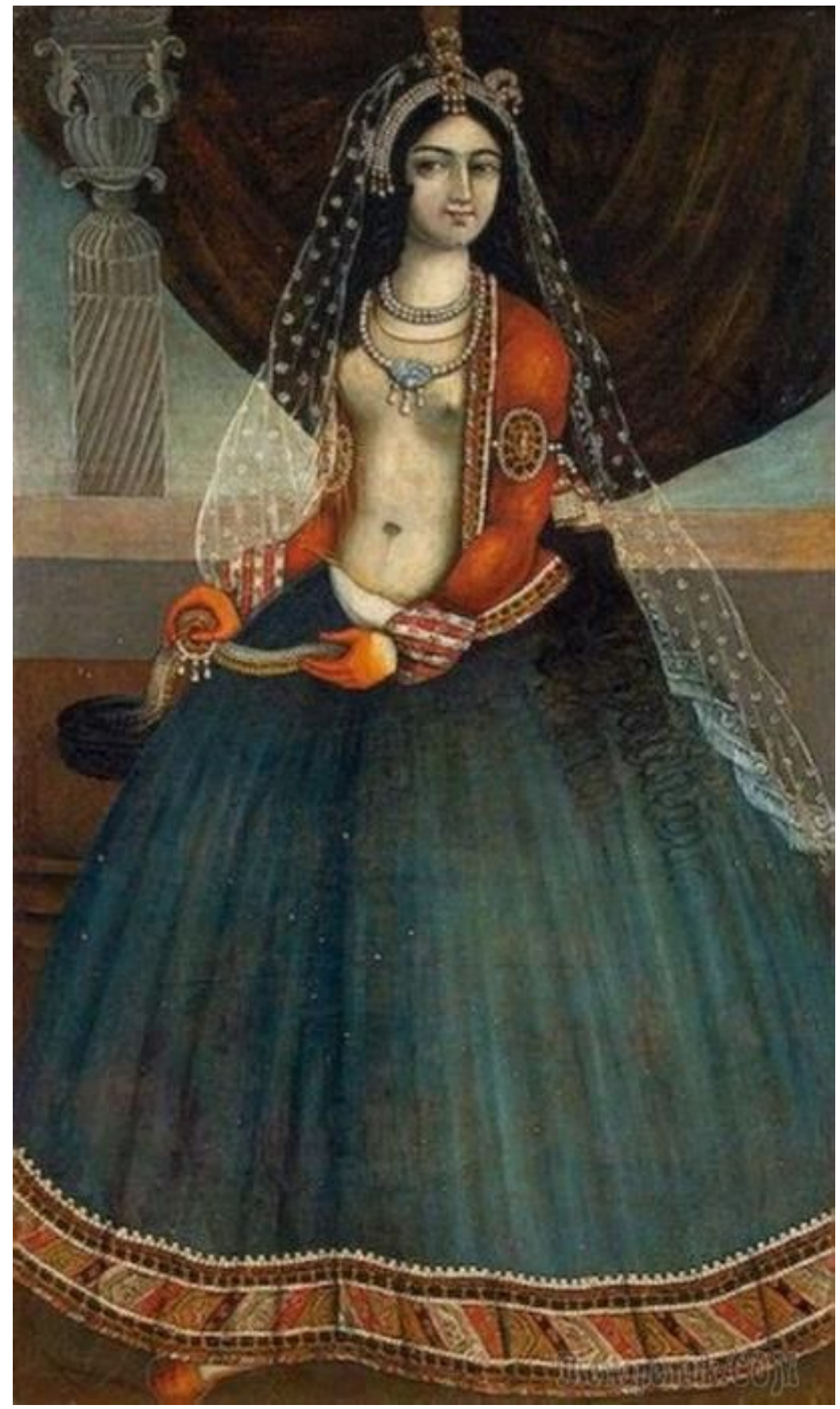

Иллюстр. 9. Женщина с диадемой. Холст, масло, клеевые краски. 150х89 см. Середина XIX в. Государственный Эрмитаж.

Неизвестный художник отказался от баланса в изображении женского тела, предпочтя актуализировать проявления именно обнаженной феминности

Figs. 9. Woman with a Diadem. Canvas, oil, glue paint. 150x89 cm. The middle of the 19th century. The State Hermitage.

Unknown artist refused balance in his portrayal of the female body, preferring to actualize a manifestation of naked femininity 


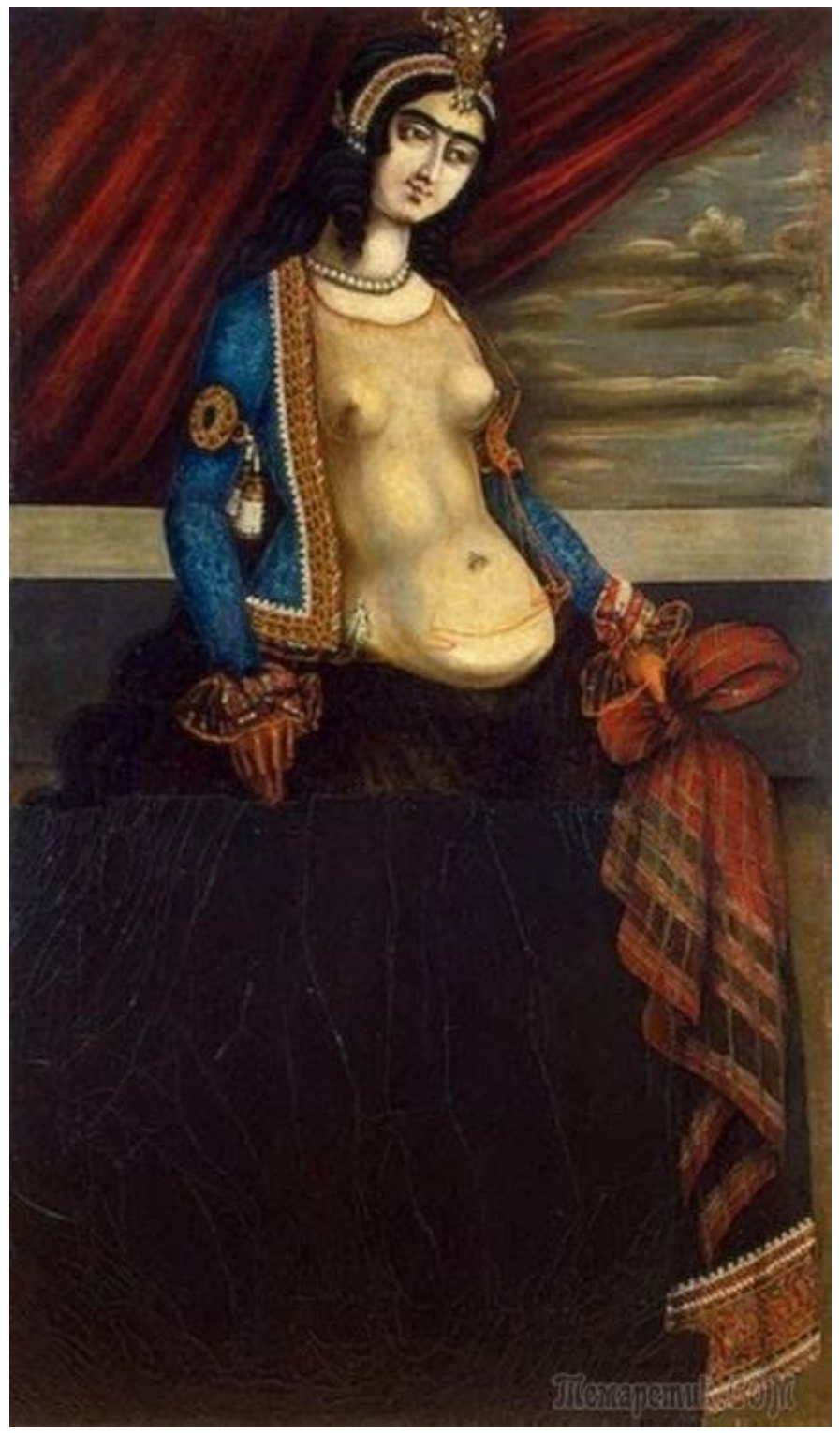

Иллюстр. 10. Женщина с шарфом. Холст, масло, клеевые краски. 145х85 см. Середина XIX в. Государственный Эрмитаж

Картина неизвестного художника середины 19 века актуализирует тенденции постепенного роста интереса к визуализации обнаженного женского тела, так и начало секуляризации персидской живописи, что проявилось в попытках трансплантации европейских элементов (фон)

Figs. 10. Woman with Scarf. Canvas, oil, glue paint. $145 \times 85 \mathrm{~cm}$. Mid 19th century. The State Hermitage Museum

This painting by an unknown artist of the mid 19th century actualizes the tendencies of gradual growth of interest in rendering of a naked female body, as well as the beginning of secularization of Persian painting, which manifested itself in the attempts of transplantation of European elements (background) 


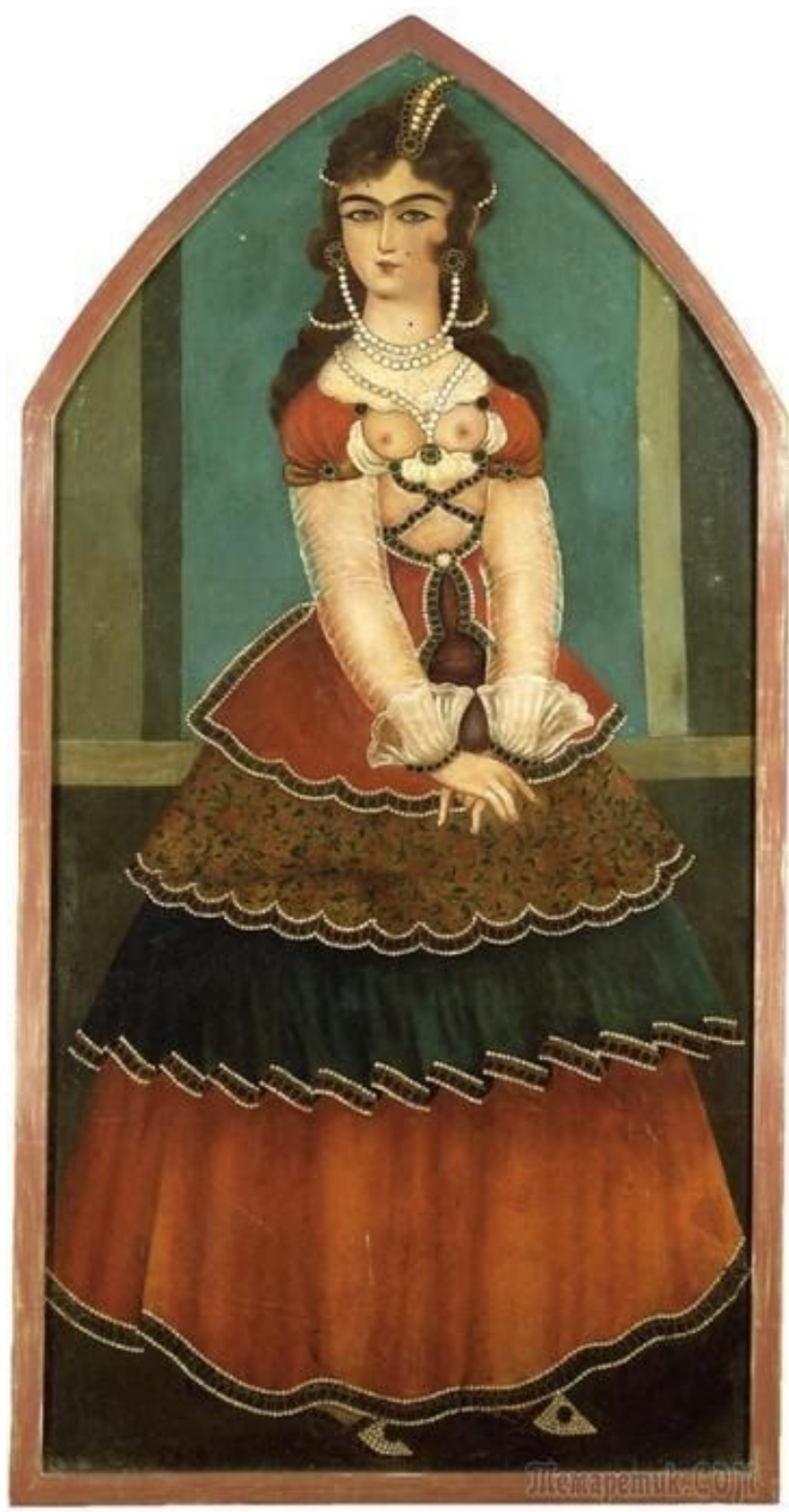

Иллюстр. 11. Неизвестный художник. Портрет женщины в платье. Холст, масло (деревянная рама); $152 x 78$ см. XIX в.

Картина демонстрирует тенденции смешения и миксации национального и европейского стилей в иранской живописи 19 столетия, актуализируя один из примеров визуализации т.н. «каджарского декольте»

Figs. 11. Unknown artist. Portrait of a Woman in Dress. Oil on canvas (wooden frame). $152 \times 78 \mathrm{~cm}$. 19th century.

The painting demonstrates the tendencies of mixing and mingling of national and European styles in the Iranian painting of the 19th century, actualizing one of the examples of the rendering of the so-called "Qajar décollete" 


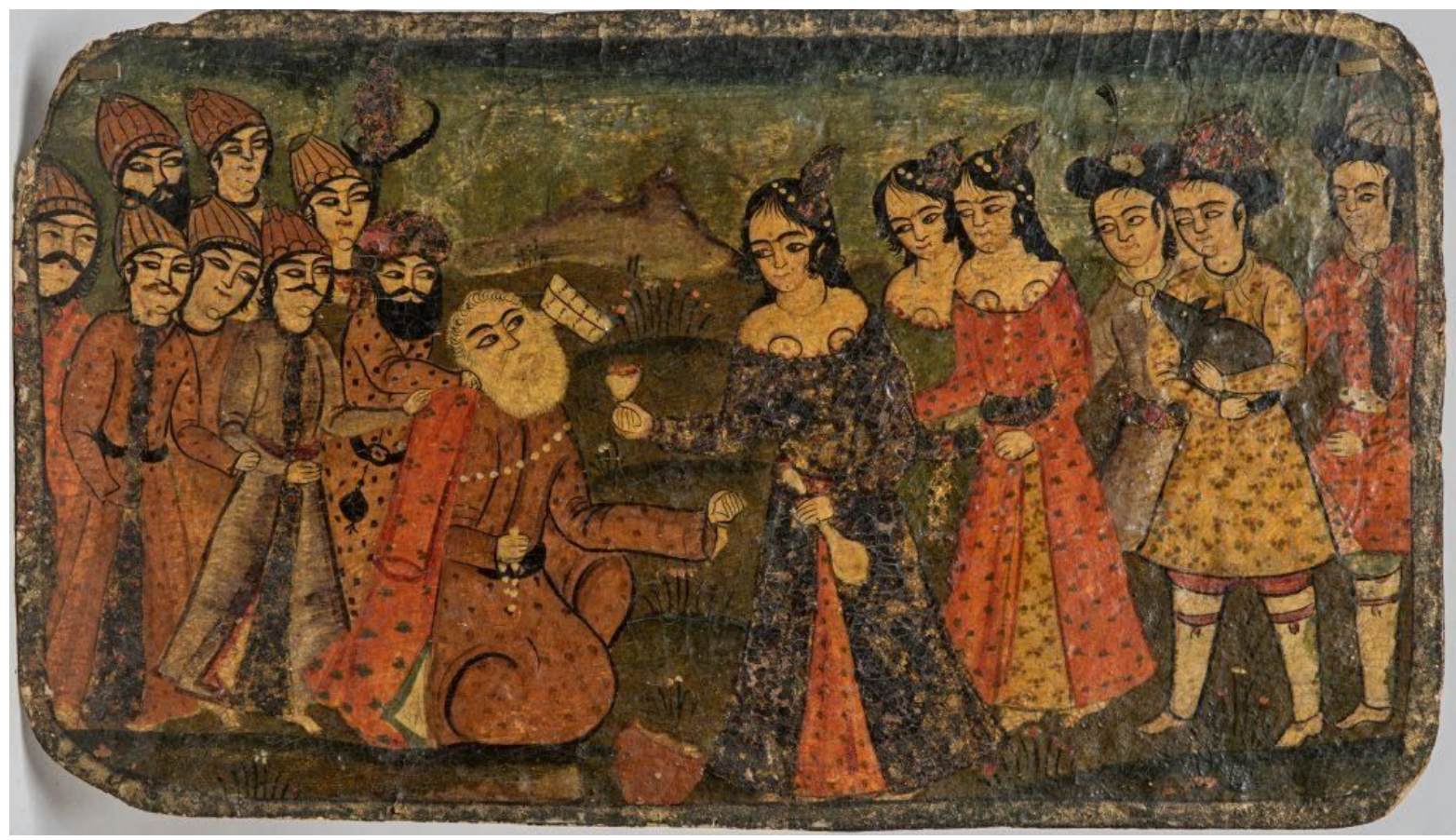

Иллюстр. 12. Сцена из «притчи о шейхе Сан 'ане» из поэмы автора конца XI - начала XII века Фарид ад-Дина Аттара «Язык птиц». Папье-маше. Роспись под лаком.

Если картины были предназначены для представителей среднего и высшего класса, то подобные предметы, которые получили большее распространение в Иране, также актуализируют образы обнаженной женской феминности, что свидетельствует о том, что процессы модернизации культурной сферы охватывали широкие социальные и культурные группы Ирана. Три женские и мужские фигуры справа - христиане, а один из них и вовсе держит в руках свинью. Примечательно, что первая женская фигура протягивает шейху бокал с вином.

Figs. 12. Scene from the "parable of Sheikh Sam 'an" from the poem "The Conference of the Birds" by Farid ud-Din Attar, the author of the late 11th and early 12th centuries. Papier-mache. Lacquer painting.

While the paintings were intended for the middle and upper classes, similar objects that became more widespread in Iran also actualized images of naked female femininity, which suggests that the processes of cultural modernization were embracing wide social and cultural groups in Iran. The three female and male figures on the right are Christians, and one of them is holding a pig.

It is noteworthy that the first female figure is holding out a wine glass to the sheikh. 


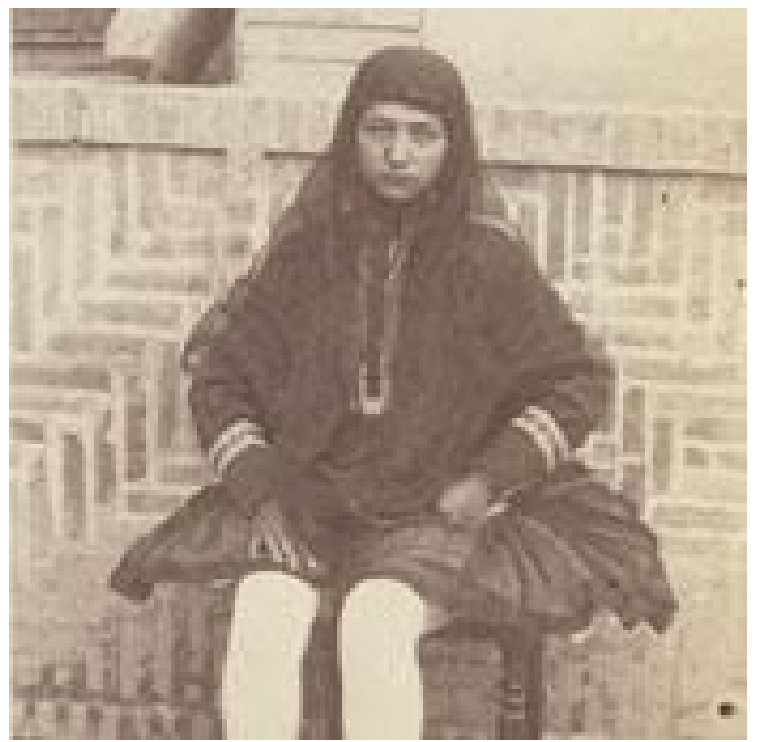

Иллюстр. 13. Захра Султан. Дочь Майме Ханум, уважающая шариат

Figs. 13. Zahra Sultan. Daughter of Mayme Khanum, who respects Shariah

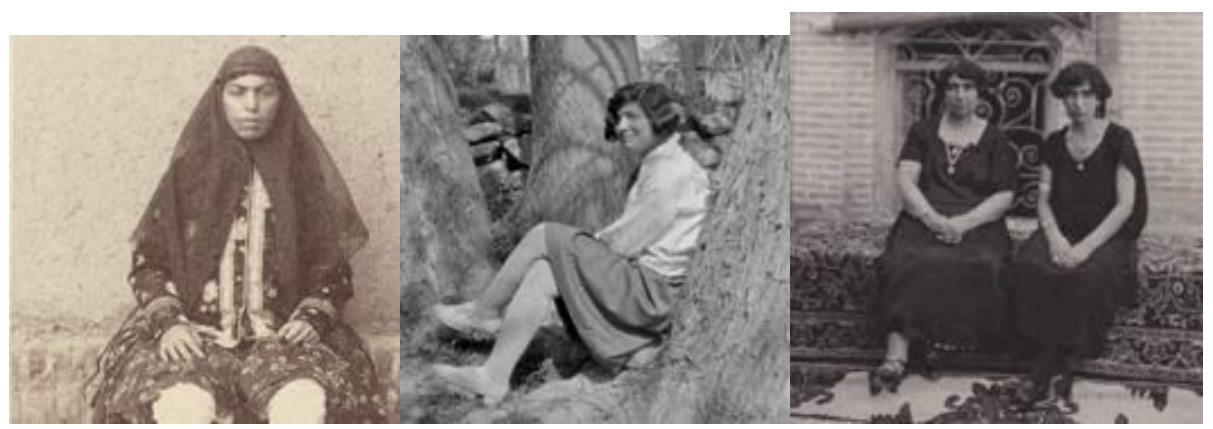

Иллюстр. 14. Женщина.

Иллюстр. 15. Женщина, сидящая у деревьев.

Иллюстр. 16. Шоку Азми и Хома Пирния

Эти четыре фотографии (13-16) периода поздних Каджаров отражают трансформации отношения к женскому телу в культурном дискурсе Персии, фиксируя как тенденции архаизации и традиционализации фотографического отражения женского тела через подчеркивания традиционной моды, так и ранние формы модернизации и европеизации, когда женщина становится не объектом фотосъемки с этнографическим и культурноантропологическим уклоном, но героем фотографии.

Figs. 14. Woman.

Figs. 15. Woman sitting by the trees.

Figs. 16. Shoku Azmi and Homa Pirnia

These four photographs (13-16) from the late Qajar period reflect transformations in attitudes toward the female body in Persian cultural discourse, recording both trends toward archaization and traditionalization of photographic reflection of the female body through emphasizing traditional fashion, and early forms of modernization and Europeanization, when the woman becomes not the object of photography with ethnographic and cultural and anthropological bias, but the hero of photography. 


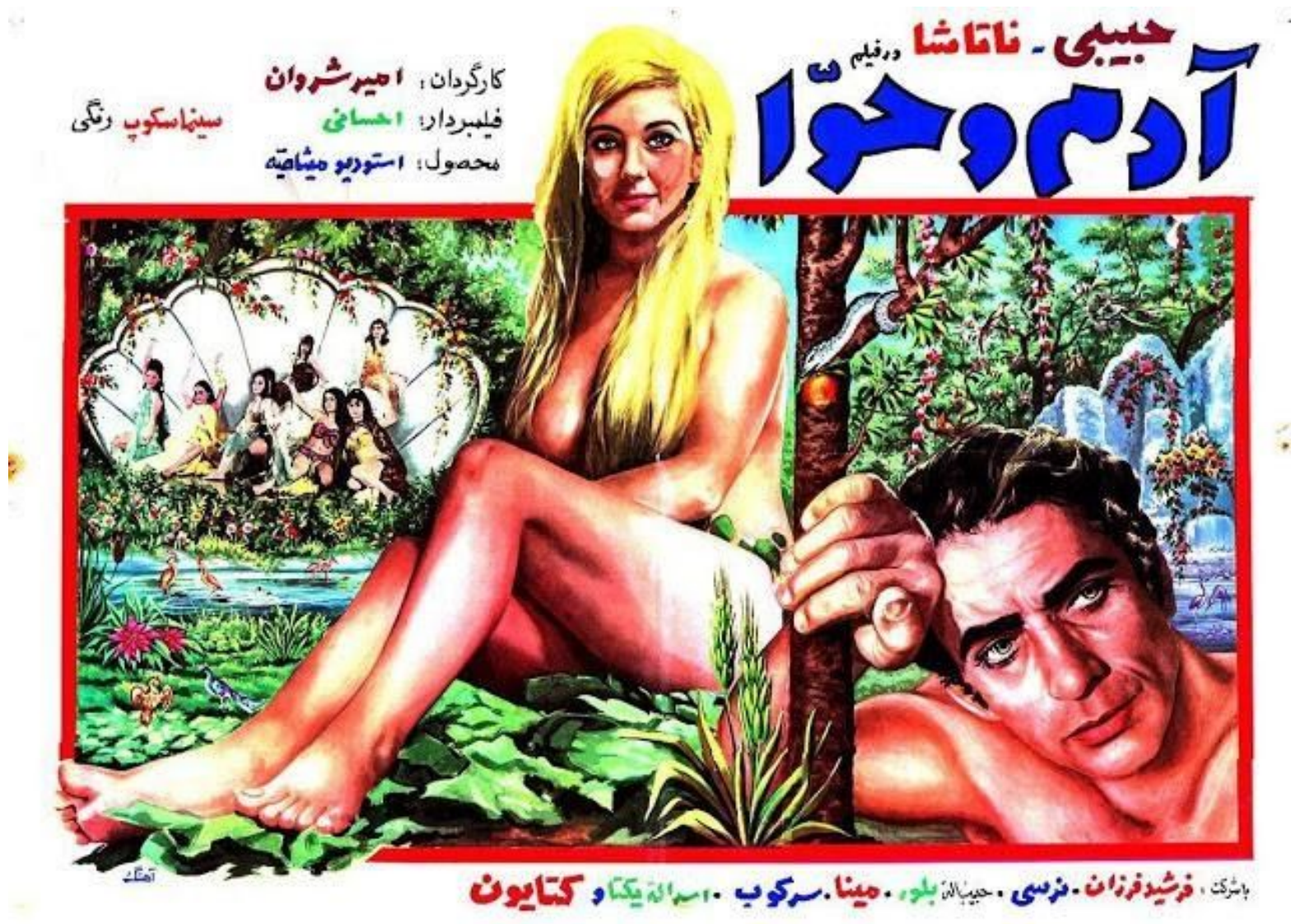

Иллюстр. 17. Постер иранского фильма «Адам и Ева», 1970.

Несмотря на тот факт, что фильм не был порнографическим, а являлся только художественным, его появление носило скандальный характер, так как фильм фактически стал одной из первых попыток открытой демонстрации на экране обнаженного женского тела в сопровождении героя-мужчины, который, по решению режиссера, тоже был почти лишен одежды. Скандальности, по мнению сторонников традиционализма, фильму добавило и то, что герой был выбрит (то есть был больше похож на европейца, чем на

иранца). Это не спасло фильм от обвинений в искажении образов мусульман и попрании норм ислама.

Fig. 17. Poster of the Iranian film "Adam and Eve", 1970.

Despite the fact that the film was not pornographic, but only fiction, its appearance was scandalous because it was one of the first attempts to openly display a naked female body accompanied by a male protagonist, who, according to the director's decision, was also almost stripped of clothes. According to the supporters of traditionalism, the fact that the hero was shaved (i.e., more like a European than an Iranian) also added to the scandalousness of the film. This did not save the film from accusations of distorting the images of Muslims and violating Islamic norms. 

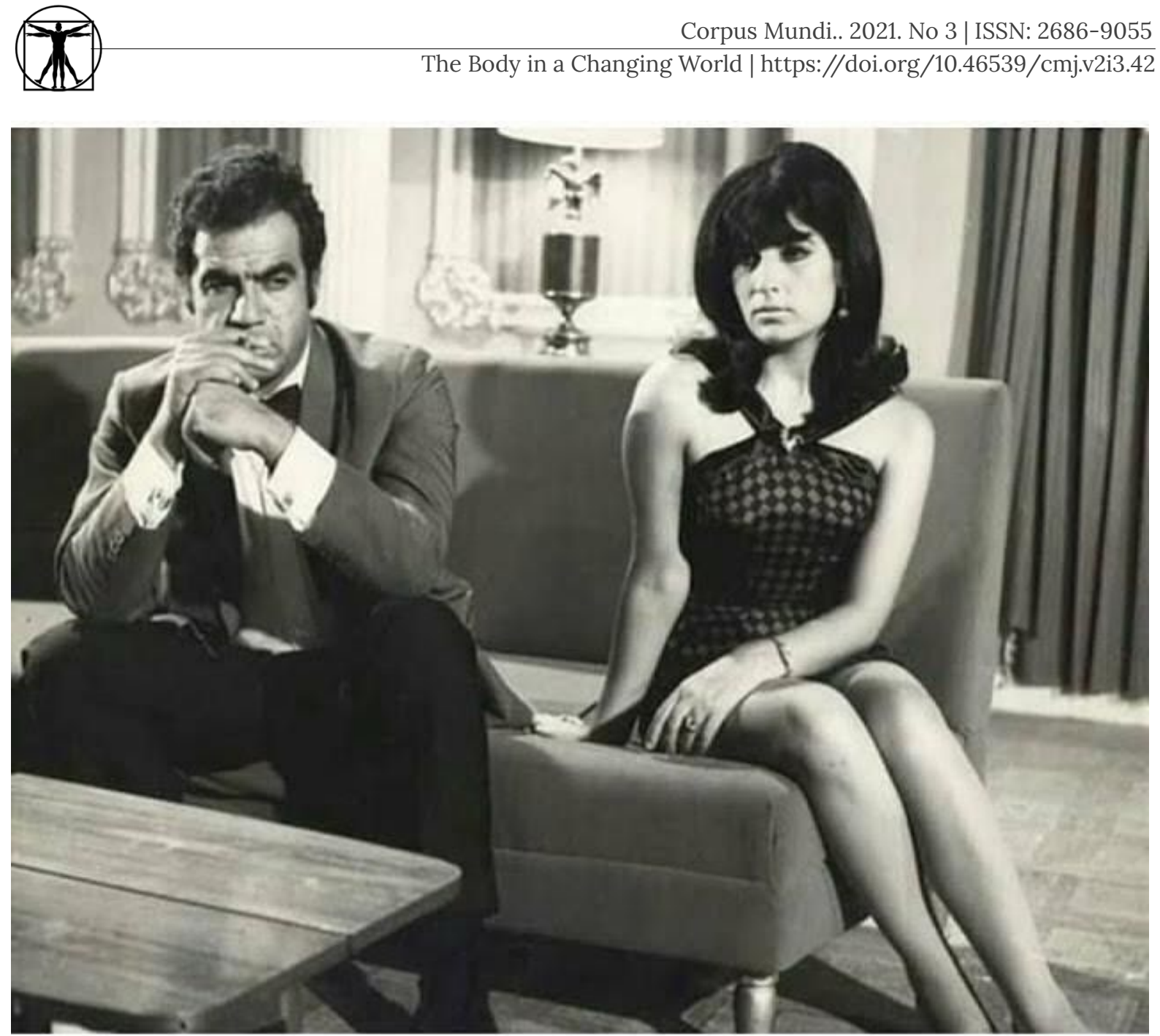

Иллюстр. 18. Кадр из фильма «Монета удачи», 1970.

"Монета удачи" - еще один фильм из культурного наследия Ирана периода династии Пехлеви, который не только визуализировал феминное тело, сексуализируя его, но и позиционировал женщину как такое же полноправное и действующее лицо как и героев-мужчин.

Fig. 18. A still from the film "Coin of Fortune," 1970.

"The Coin of Fortune" is another film from the cultural heritage of Iran during the Pahlavi dynasty, which not only visualized the feminine body by sexualizing it, but also positioned the woman as a full and equal actor as the male protagonists. 


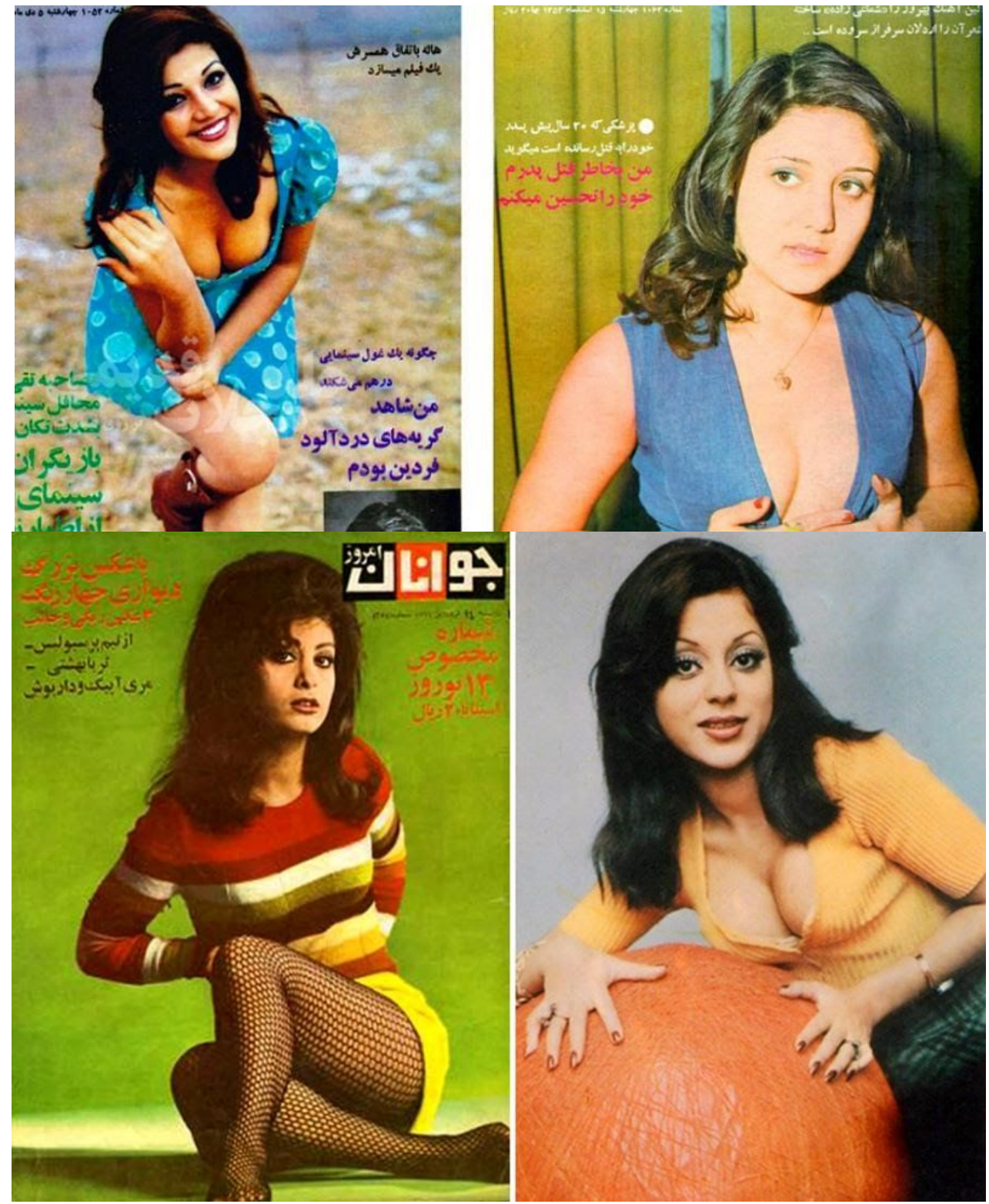

Иллюстр. 19 - 22. Обложки иранских женских журналов 1970-х гг.

Фотографии, размещенные на обложках иранских женских журналов 1970-х годов в определенной мере продолжают и развивают традицию «каджарского декольте» с той лишь разницей, что модели не только более реальны, чем героини каждарской портретной живописи 19 века, но и даже более скромны, так как демонстрируют не обнаженную грудь, а именно декольте

\section{Fig. 19 - 22. The covers of Iranian women's magazines of the 1970s.}

The photographs on the covers of Iranian women's magazines of the 1970s to a certain extent continue and develop the tradition of "Qajar decollete" with the only difference being that the models are not only more real than the heroines of 19th century Qajar portraiture, but are even more modest, as they show not a naked breast but precisely the decollete 


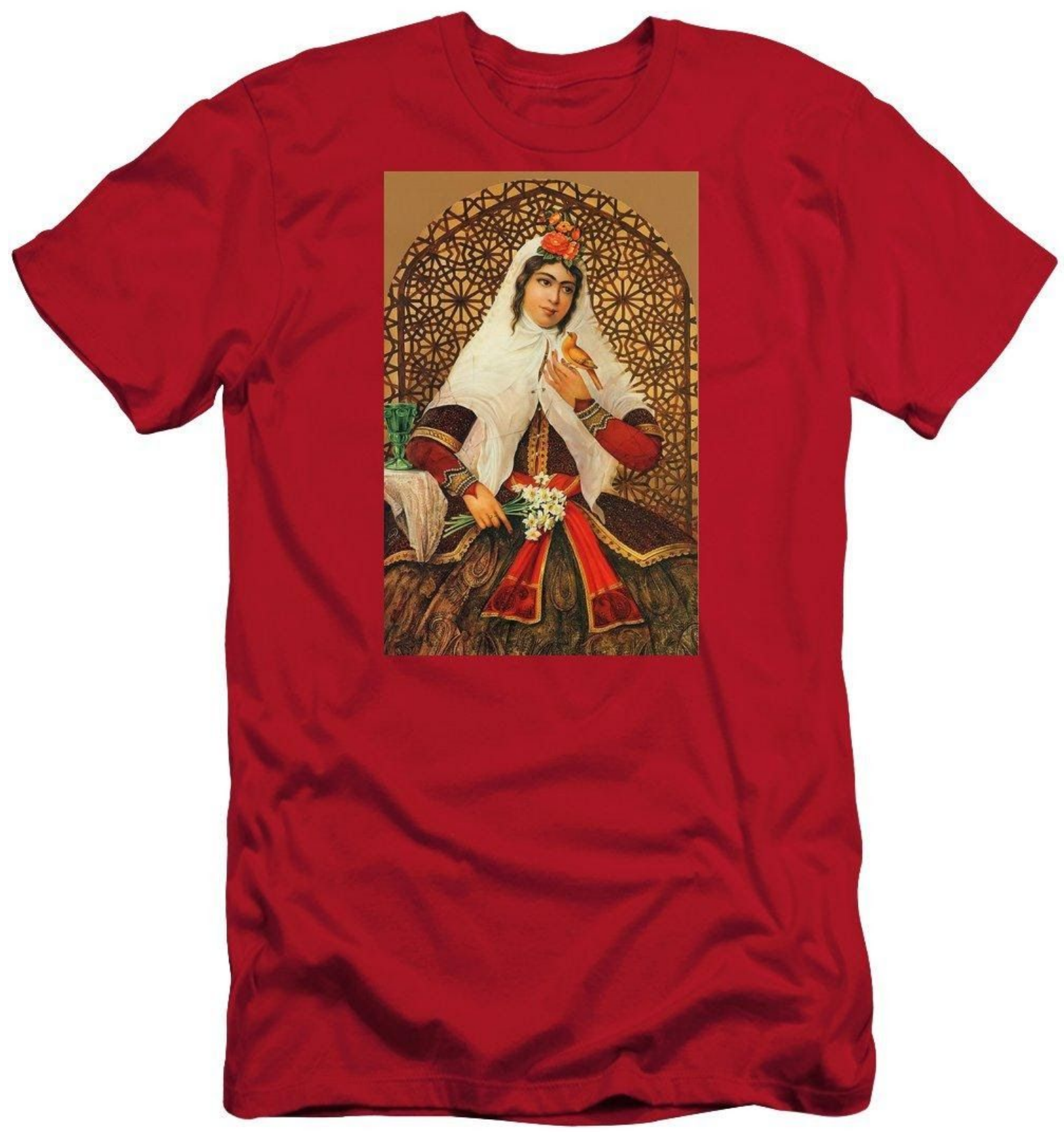

Иллюстр. 23. Qajar Woman by Shakira Premium T-Shirt.

Fig. 23. Qajar Woman by Shakira Premium T-Shirt. 


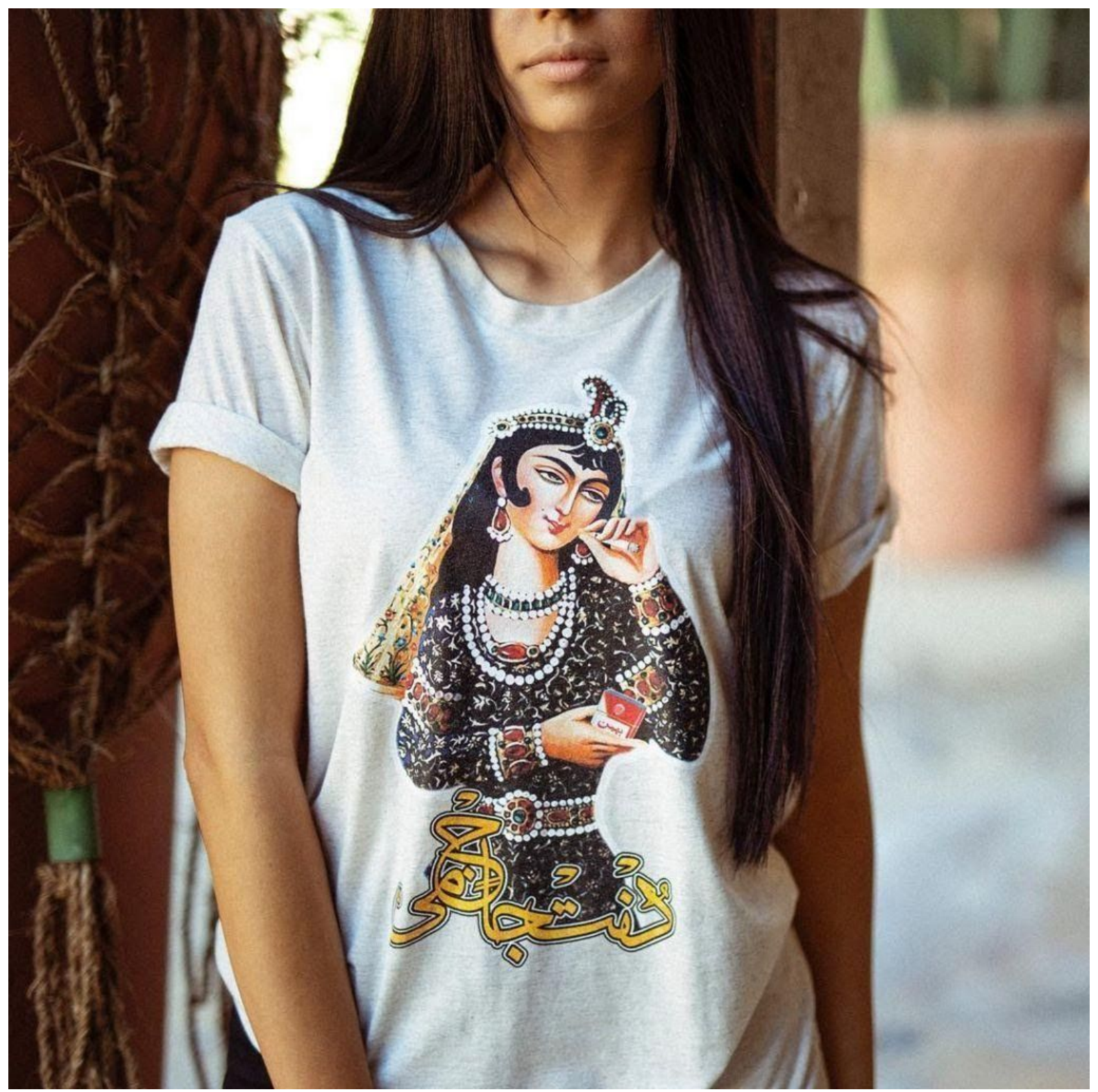

Иллюстр. 24. Persian Inspired T-Shirt

Fig. 24. Persian Inspired T-Shirt 


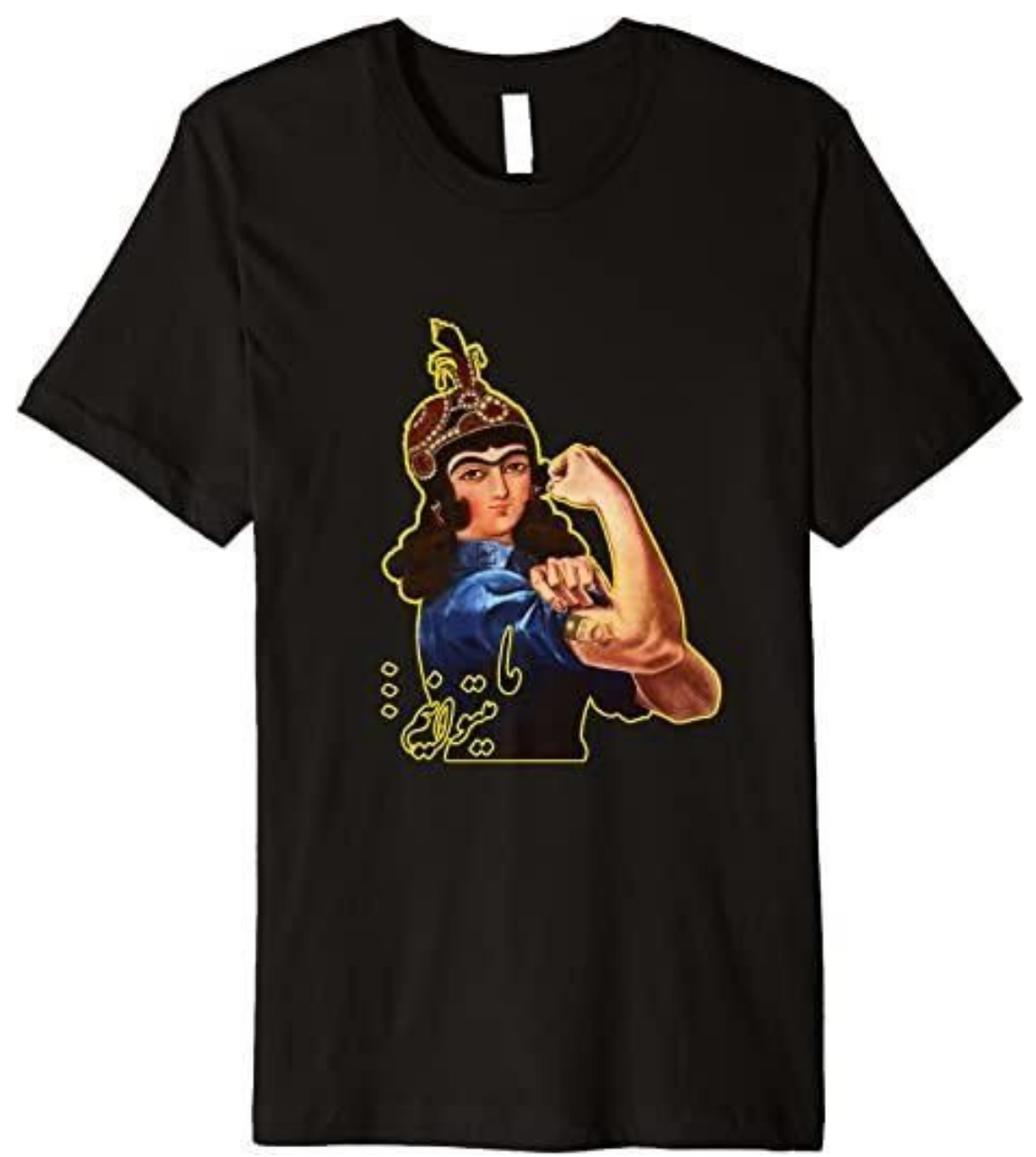

Иллюстр. 25. Persian Qajar Princess - We Can Do It Premium T-Shirt.

Предметы повседневной моды в различной степени актуализируют визуальные феминные образы живописи Ирана эпохи Каджаров, свидетельствуя о том, что официальный дискурс культуры и моды развивается параллельно тому, который в большей степени подвержен

маркетизации, так как ориентирован на рыночный спрос и обслуживает интересы массовой культуры и потребности связанного с ней общества потребления. Если на официальном уровне в Исламской Республике Иран культура Персии эпохи Каджаров маргинализируется, так как именно в 19 веке усилилось негативное, по мнению властей, западное и российское влияние, то на уровне индустрии моды культурное наследие ранней персидской модернизации оказывается вполне успешно продаваемым.

\section{Fig. 25. Persian Qajar Princess - We Can Do It Premium T-Shirt.}

Everyday fashion items to varying degrees actualize the visual feminine images of Qajar-era Iranian painting, indicating that the official discourse of culture and fashion develops in parallel with the one that is more susceptible to marketization, as it is oriented toward market demand and serves the interests of mass culture and the needs of the consumer society associated with

it. If at the official level in the Islamic Republic of Iran, the culture of Qajar-era Persia is marginalized because it was in the 19th century that the negative, in the opinion of the authorities, Western and Russian influence increased, then at the level of the fashion industry the cultural heritage of early Persian modernization turns out to be quite successfully marketed. 

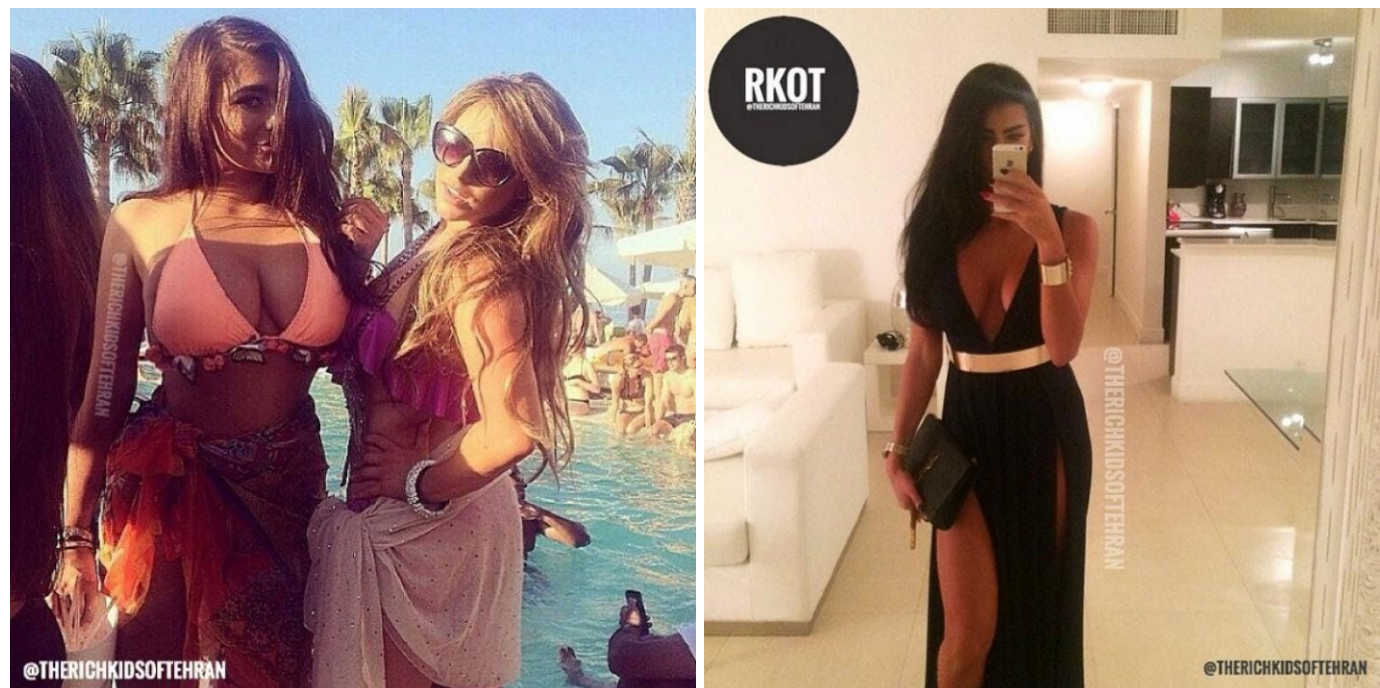

Иллюстр. 26 - 27. Фотографии, размещенные в инстраграм-канале «Rich Kids of Tehran»

Фотографии представителей «золотой молодежи» Ирана из инстраграм-канала «Rich Kids of Tehran». Стилистически и содержательно подобные фотографии актуализируют тенденции унификации и сериализации в визуальном воспроизводстве и фиксации образов женского тела в частности и феминной телесности в целом в современном Иране несмотря на необходимость следовать формально жестким регламентациям и предписаниям, связанным с нормами мусульманского дресс-кода, которые на приведенных в качестве примера фотографиях нарушаются и игнорируются, что актуализирует состояние множественности практик отражения феминнной телесности в интернет-пространстве.

\section{Fig. 26 - 27. Photos posted on the "Rich Kids of Tehran" instragram channel}

Photos of Iran's "golden youth" from the "Rich Kids of Tehran" instragram channel. Stylistically and content-wise such photos actualize the tendencies of unification and serialization in the visual reproduction and fixation of images of the female body in particular and feminine corporeality in general in modern Iran, despite the need to follow the formally strict regulations and prescriptions associated with the norms of Muslim dress code, which in these examples of photos are broken and ignored, which actualizes the state of multiplicity of practices of reflecting feminine corporeality in the Internet space. 


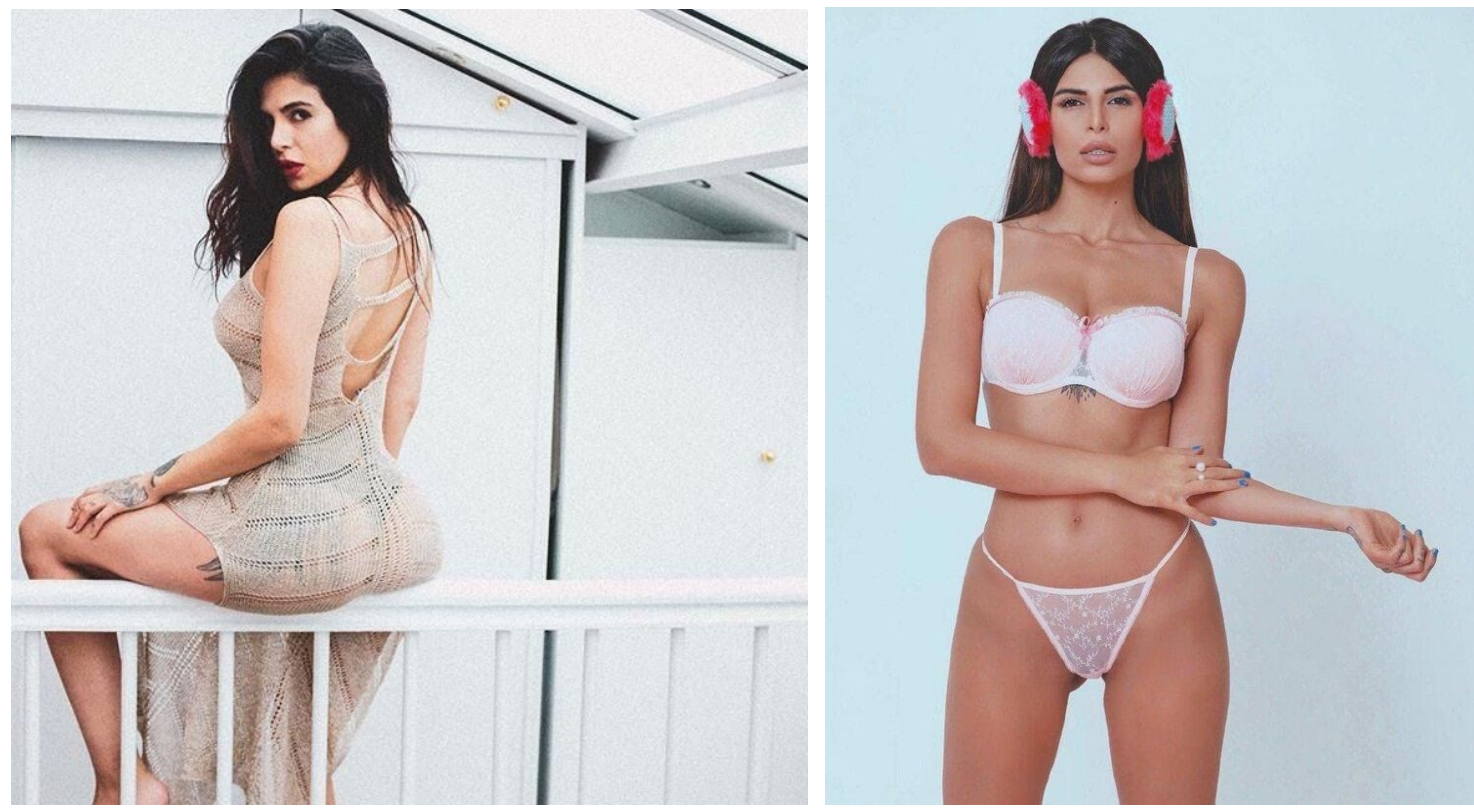

Иллюстр. 28 - 29. Фотографии иранской модели известной как Негзия, опубликованные в 2017 г. западными СМИ и ставшие причиной ее эмиграции из Ирана.

Иранская модель Негзия была вынуждена покинуть Иран после того, как эти ее фотографии были опубликованы СМИ. В Иране ее участие в такой фотосессии было воспринято крайне негативной, ей начали не только поступать угрозы, но она была вынуждены эмигрировать во Францию. Если такие относительно умеренно и консервативные попытки фотографической фиксации феминной телесности в Иране выглядят недопустимыми и маргинальными, то в контекстах современной визуализации женской телесности в массовой культуре общества потребления Запада и России они более чем консервативны и несопоставимы с теми фотографиями, которые некоторыми пользователями размещаются на своих страницах в социальных сетях.

\section{Fig. 28 - 29. Photos of an Iranian model known as Negzzia, published in 2017 by the Western} media, which caused her emigration from Iran.

Iranian model Negzzia was forced to leave Iran after these photos of her were published by the media. In Iran, her participation in such a photo shoot was perceived extremely negatively, not only did she start receiving threats, but she was forced to emigrate to France. If such relatively moderate and conservative attempts at photographic fixation of feminine corporeality in Iran seem unacceptable and marginal, then in the context of the contemporary visualization of female corporeality in the mass culture of Western and Russian consumer society they are more than conservative and incomparable to the pictures that some users post on their social media pages. 


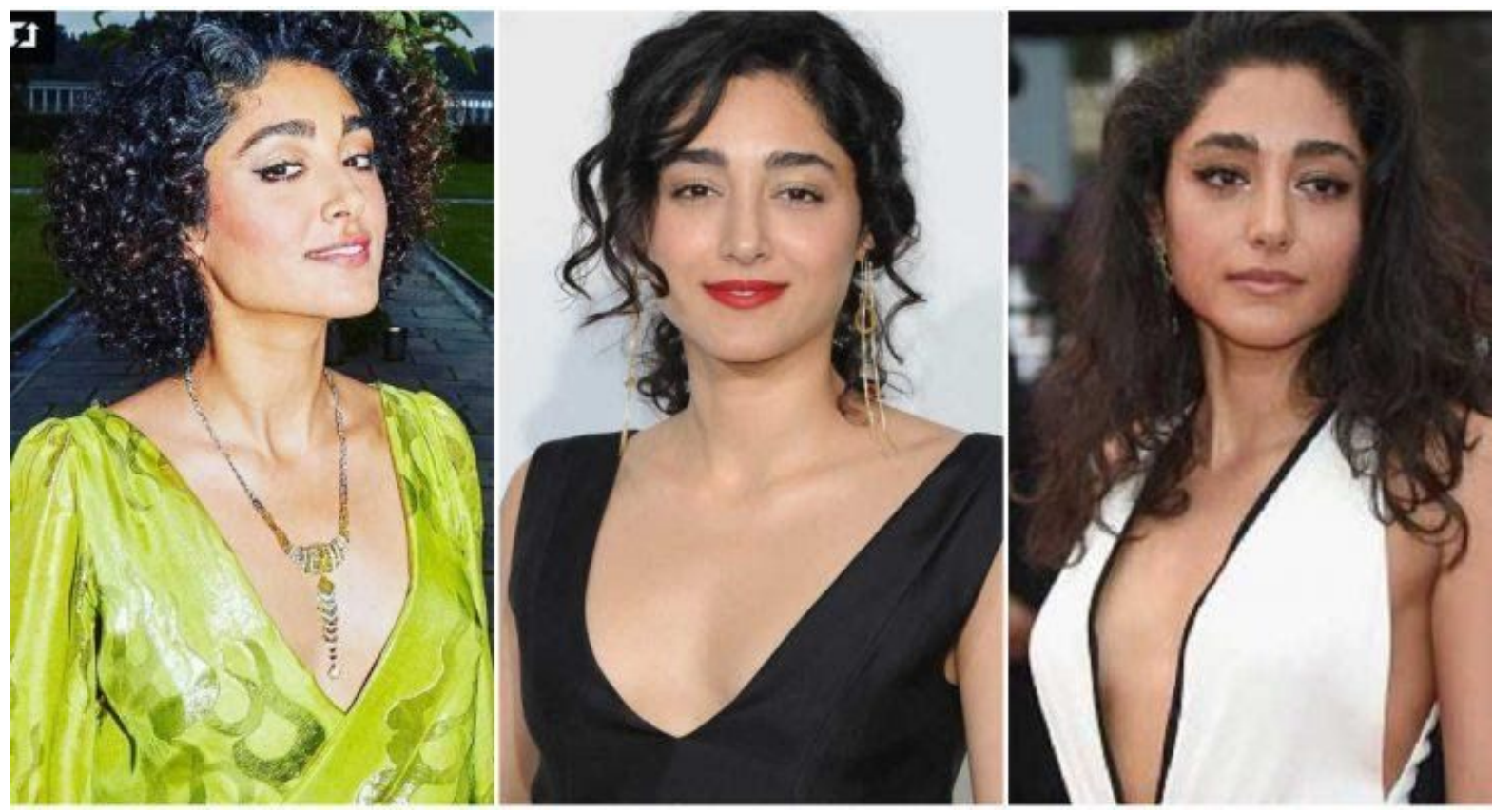

\section{Иллюстр. 30 - 32. Гольшифте Фарахани - французская актриса иранского происхождения}

Фотографии Гольшифте Фарахани выглядят вполне умеренными и даже консервативными в контекстах современной массовой культуры Запада, но отношение в Исламской Республике Иран к ним не столь однозначно, так как на исторической родине актриса воспринимается как аморальная и скандальная фигура как в силу того, что снимается в Европе, так и от того, что в сети доступны ее фотографии не только с непокрытой головой и открытыми плечами, но и с обнаженной грудью, которые откровенно актуализируют и демонстрируют сексуальность обнаженного женского тела, что противоречит тем представлениям о феминной телесности, которые имеют в ИРИ статус официальных.

\section{Fig. 30 - 32. Golshifteh Farahani is a French actress of Iranian origin}

Golshifteh Farahani's photographs look quite moderate and even conservative in the context of modern Western mass culture, but the attitude in the Islamic Republic of Iran is not so unequivocal, because in her historical homeland the actress is perceived as an immoral and scandalous

figure due to her filming in Europe, and because her photographs with uncovered head and open shoulders, and with exposed breasts, which openly actualize and demonstrate the sexuality of the naked female body, are available online. 


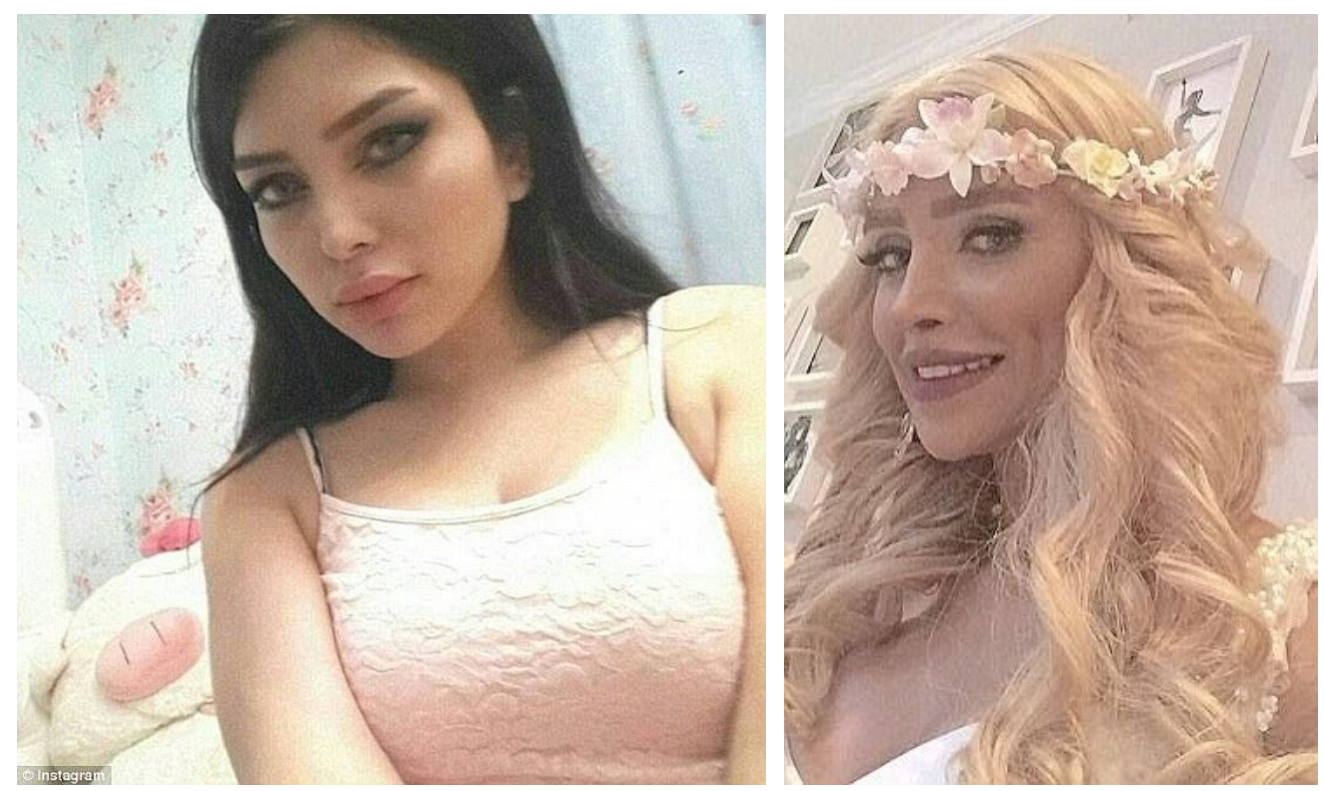

\section{Иллюстр. 33 - 34. Нилофар Бехбуди и Эльхам Араб - иранские модели, осужденные в ИРИ в 2016 г.}

Нилофар Бехбуди и Эльхам Араб - иранские модели, осужденные в ИРИ в 2016 г. получили известность как модные блоггеры, которые снимали ролики, посвященные вопросам женской моды. Эльхам Араб, в частности, была известна своими попытками продвижения и популяризации в Иране западной свадебной моды. Модели были обвинены

в распространении порнографии, хотя стилистика их фотографий в определенной степени, действительно, содействует превращению женского тела в не более чем предмет

пространственной организации, но это не может быть поводом для обвинения в распространении порнографии, так как модели только копировали, имитировали и

симулировали западный канон визуальной фиксации феминной телесности, в

значительной степени основанный именно на сексуализации. Модели подверглись судебному преследованию за формальное нарушение предписываемого мусульманского дресс-кода, так как на большинстве их фотографий и в своих роликах они фигурируют без хиджаба, обнажая руки, плечи и зону декольте, что сторонниками официальной линии в развитии моды в Исламской Республике Иран было воспринято крайне негативно. Другой причиной отторжения консервативным большинством стало и то, что визуальные образы

этих моделей практически не соотносятся с официальным исламским дискурсам, в большей степени принадлежа к западной культуре потребления.

Figs. 33 - 34. Niloofar Behboudi and Elham Arab are Iranian models convicted in IRI in 2016.

Niloofar Behboudi and Elham Arab are Iranian models convicted in IRI in 2016. - gained notoriety as fashion bloggers who made videos on women's fashion issues. Elham Arab, in particular, was known for her attempts to promote and popularize Western wedding fashion in Iran. The models were accused of spreading pornography, although the stylistics of their photographs do, to a certain extent, promote the transformation of the female body into nothing more than an object of spatial organization, but this cannot be a reason to accuse them of spreading pornography, since the models only copied, imitated and simulated the Western canon of visual fixation of feminine corporeality, largely based specifically on sexualization. The models were prosecuted for formally violating the prescribed Muslim dress code, since in most of their photographs and in their videos they appear without a hijab, exposing their arms, shoulders and cleavage zone, which supporters of the official line in the development of fashion in the Islamic 
Republic of Iran perceived extremely negatively. Another reason for the rejection by the conservative majority was the fact that the visual images of these models hardly correlate with official Islamic discourse, belonging more to the Western consumer culture.

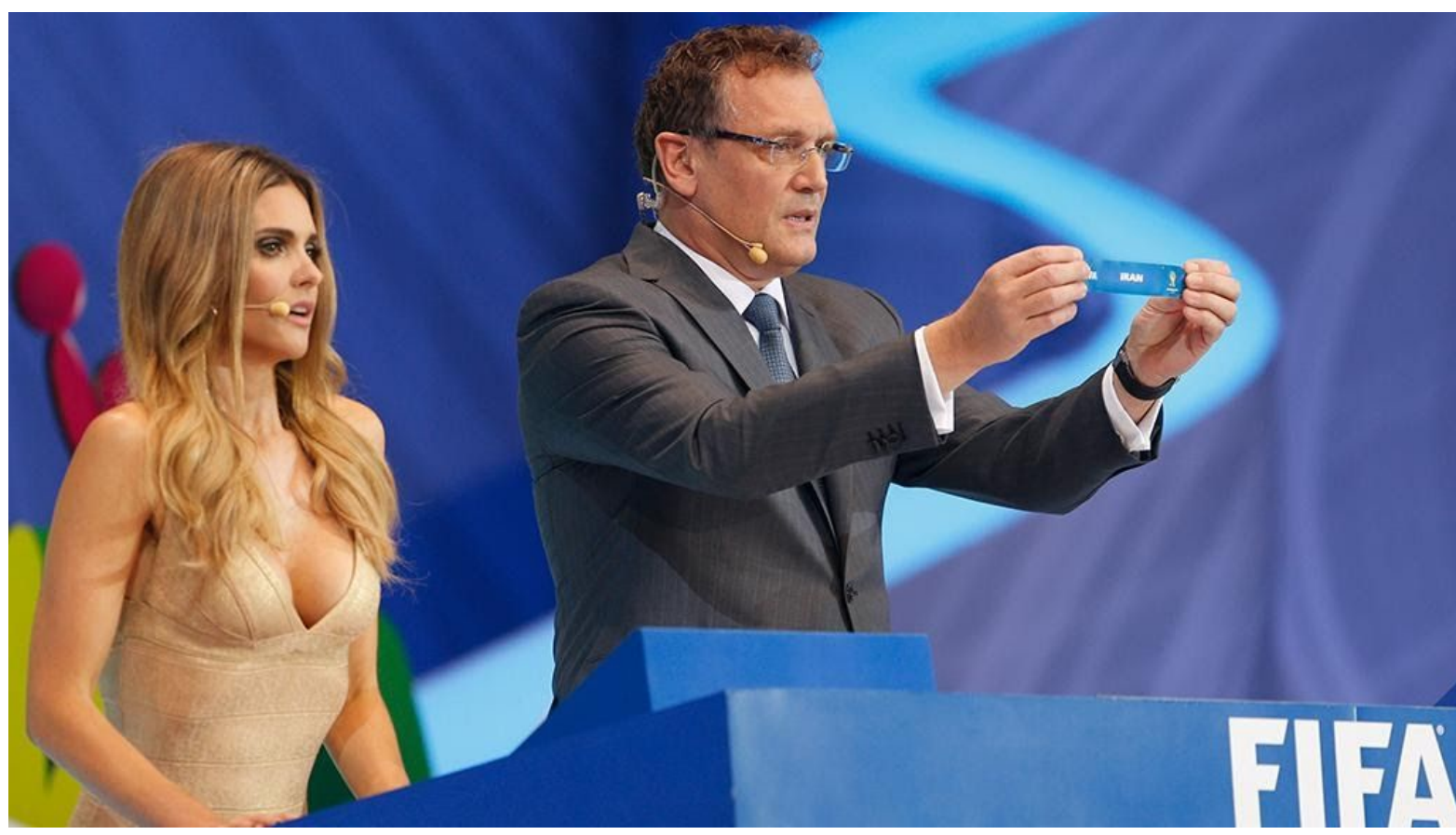

Иллюстр. 35. Бразильская модель Фернанда Лима на церемонии жеребьевки командучастниц ФИФА 2014 г.

Государственная телекомпания Ирана прекратила трансляцию мероприятия сразу же после того, как в кадре появилась бразильская модель в платье с декольте, которое не соответствовало требованиям и нормам мусульманской моды. В результате иранские болельщики узнали из других источников, что сборная Ирана попала в Группу F вместе с Аргентиной, Нигерией и Боснией и Герцеговиной.

Fig. 35. Brazilian model Fernanda Lima at the FIFA 2014 team draw ceremony.

Iran's state broadcaster stopped broadcasting the event immediately after a Brazilian model appeared in the frame wearing a dress with decollete that did not conform to Muslim fashion requirements and norms. As a result, Iranian fans discovered from other sources that the Iranian team was placed in Group F along with Argentina, Nigeria, and Bosnia and Herzegovina. 


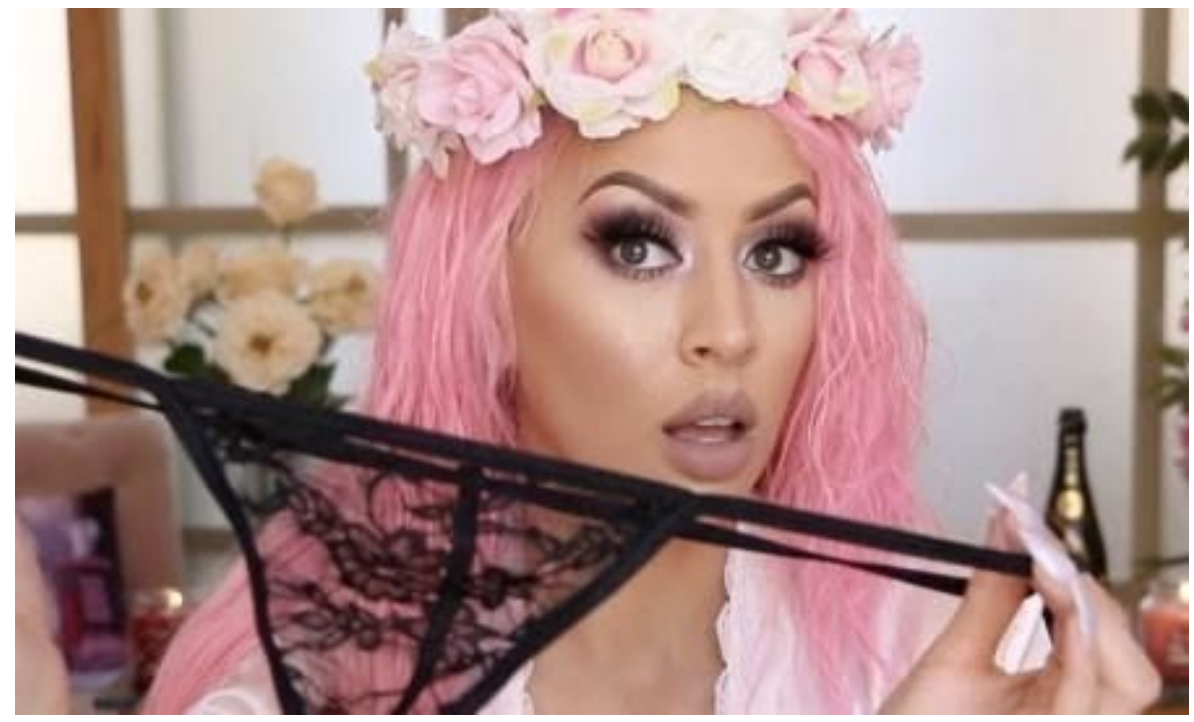

Иллюстр. 36. Реклама женского белья в Иране в условиях цензурных ограничений.

Несмотря на то, что в Исламской Республике Иран на демонстрацию женского тела, тем более - обнаженного, как в публичных пространствах, так и в интернете существуют значительные ограничения - это не исключает визуализации феминной телесности в современной иранской массовой культуре. При этом общество потребления в Иране практически ничем не отличается от западного общества, так как женское тело подвергается объективизации, что проявляется через актуализацию женской сексуальности. Женское тело на данной фотографии редуцировано до лица, шеи и частично рук. Подобные визуальные стратегии актуализации феминного тела в определенной степени содействуют и его порнификации, что в Иране, в условиях наличия цензурных ограничений, проявляется в меньшей степени, чем в западной культуре потребления, хотя частная сфера жизни иранцев исламистским режимом контролируется в меньшей степени и, поэтому, в социальных сетях, особенно - в западных, и на страницах иранцев в диаспоре можно обнаружить и радикальные формы визуализации телесности.

Fig. 36. Advertising of women's underwear in Iran under censorship restrictions.

Despite the fact that in the Islamic Republic of Iran there are significant restrictions on the display of the female body, especially the nude, both in public spaces and on the Internet, this does not exclude the visualization of the feminine corporeality in contemporary Iranian mass culture. At the same time, Iranian consumer society is virtually no different from Western society, as the female body is objectified, which manifests itself through the actualization of female sexuality.

The female body in this photograph is reduced to the face, the neck, and partially the arms. Such visual strategies of actualization of the feminine body contribute to a certain extent to its pornification, which in Iran, in the presence of censorship restrictions, is less evident than in Western consumer culture, although the private sphere of Iranian life is less controlled by the Islamist regime and, therefore, in social networks, especially in Western ones, and in the pages of Iranians in the diaspora one can also discover radical forms of visualization of the body. 


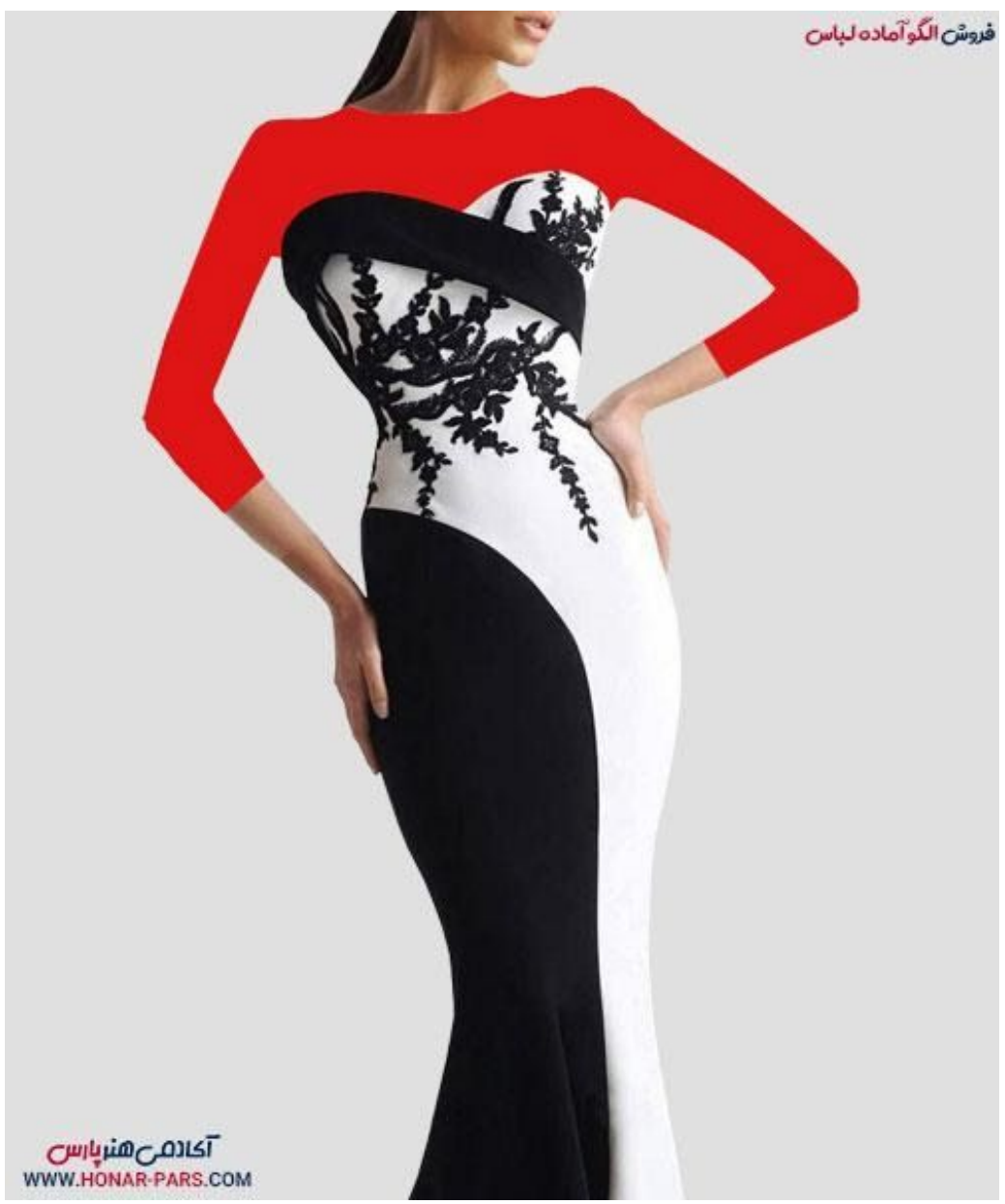

Иллюстр. 37. Готовая выкройка платья с макси-декольте.

Пример цензуры женского тела в современном Иране. На рекламе выкройки женского платья красным цветом закрашены обнаженные руки и плечи модели. Примечательно в этой ситуации и то, что в такой отцензурированной и ретушированной версии данная выкройка отнесена к категории «макси-декольте».

\section{Fig. 37. Ready-made dress pattern with maxi-decollete.}

An example of the censorship of the female body in modern Iran. In the advertisement for a woman's dress pattern, the model's naked arms and shoulders are painted in red. It is also noteworthy in this situation that in this censored and retouched version this pattern is categorized as a "maxi-decollete". 

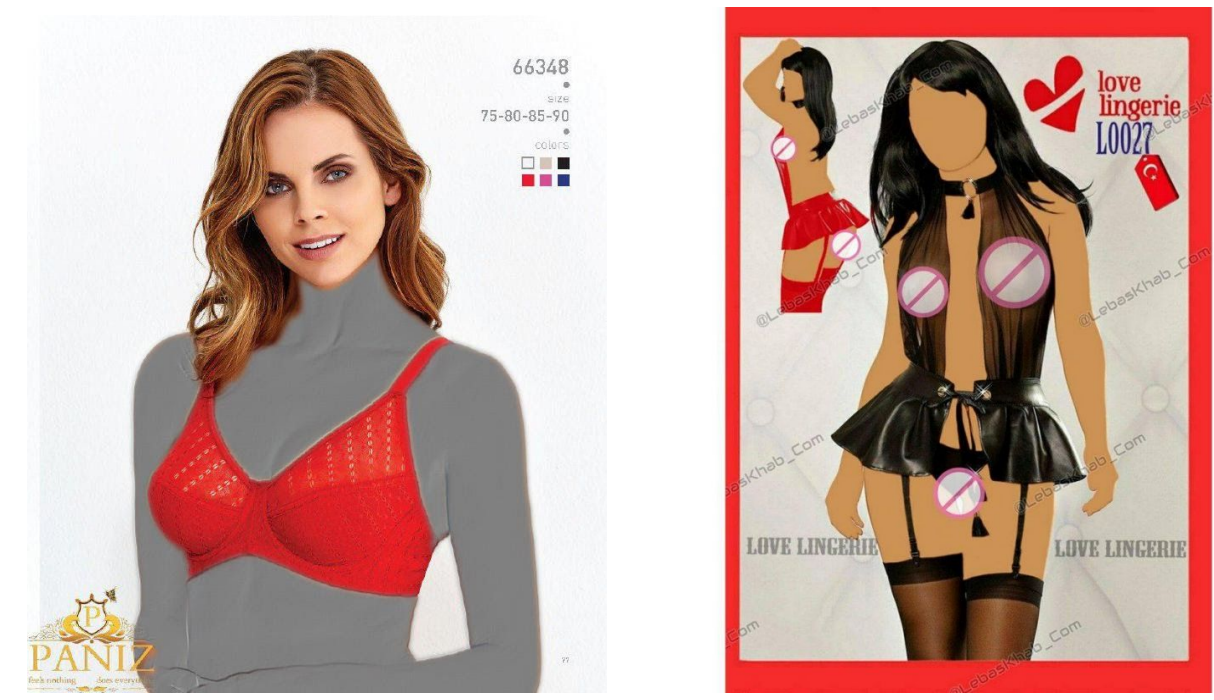

\section{Иллюстр. 38 - 39. Примеры цензурирования женского тела в современных интернет- магазинах Ирана.}

Феминная телесность, особенно в тех случаях, если она в той или иной степени обнажена, в современном Иране подвергается цензурированию, в том числе - и в рекламе интернетмагазинов женского нижнего белья. На иллюстрации слева мы видим «мягкий» вариант цензуры женского тела, где маркером заштриховано всё тело, за исключением лица. На иллюстрации справа цензурировании подверглось не только тело, грудь и зона половых органов, но и само лицо. Примечательно и то, что иллюстрация справа в определенной степени содействует порнификации женского тела, так как содержит явные отсылки к

«культуре для взрослых». Примечательно и то, что белье на иллюстрации справа позиционируется как lebās-e xāb, т.е. «одежда для сна». Реклама подобного фактически эротического нижнего белья на иранских сайтах сопровождается пояснением, в котором указывается, что «такие пижамы женщины используют, чтобы усилить и стимулировать желание мужа и побудить человека, стоящего перед ними, иметь с ними отношения с большим энтузиазмом и удовлетворением, потому что отношения очень важны для любой

пары и имеют прямое влияние на укрепление основ семьи. Женщинам не следует относиться к своей сексуальности легкомысленно и упускать из виду ее важность. Дорогие иранские женщины, вы должны создавать разнообразие для своих мужей в отношениях. Яркие и привлекательные пижамы - одна из возможных вариаций секса по невысокой цене» (Set-e lebās-e... 2020). В этой аннотации, с одной стороны, заметно признание женской сексуальности, но, с другой, ее локализация ограничивается только официальным браком.

\section{Fig. 38 - 39. Examples of the censorship of the female body in contemporary Iranian on- line stores.}

The feminine corporeality, especially when it is exposed to some degree, is censored in modern Iran, including in the advertisements of online stores of women's underwear. In the illustration on the left we see a "soft" version of censorship of the female body, where the entire body is shaded with a marker, except for the face. In the illustration on the right, not only the body, breasts, and genital area were censored, but also the face. It is also noteworthy that the illustration on the right contributes to a certain extent to the pornification of the female body, as it contains explicit references to "adult culture". It is also noteworthy that the lingerie in the illustration on the right is positioned as lebās-e xāb, i.e., "clothes for sleeping". Advertisements for 
such virtually erotic underwear on Iranian websites are accompanied by an explanation stating that "such pajamas are used by women to enhance and stimulate the desire of their husbands and to encourage the man to have a relationship with them with great enthusiasm and satisfac-

tion, because relationships are very important to any couple and have a direct impact on strengthening the foundation of the family. Women should not take their sexuality lightly and overlook its importance. Dear Iranian women, you should create variety for your husbands in the relationship. Bright and attractive pajamas for a difference in sexual life at an affordable price" (Set-e lebās-e... 2020). In this annotation, on the one hand, there is a noticeable recognition of female sexuality, but, on the other hand, its localization is limited to formal marriage.

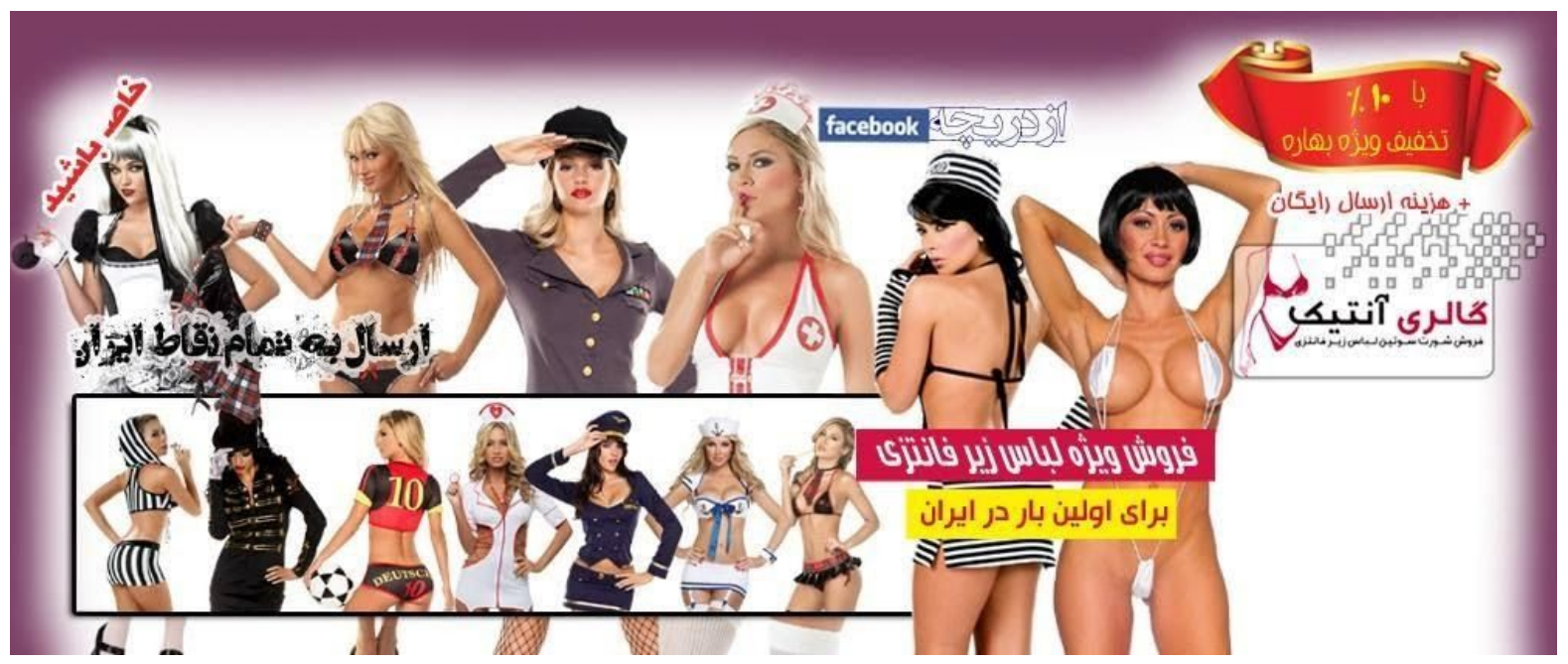

Иллюстр. 40. Реклама одного из интернет-магазинов нижнего белья в Иране.

Данная реклама представляет собой пример агрессивного маркетинга, основанного на актуализации сексуализированной или даже порнифицированной феминной телесности. В условиях существования в Иране исламистского режима данный интернет-магазин в качестве своей специализации указывает «продажу шорт, модных бюстгальтеров, нижнего белья», указывая на то, что возможна «отправка во все уголки Ирана» (Gāleri-ye āntik... 2021). Несмотря на официальный запрет порно в Иране, некоторые образцы рекламной продукции основаны на актуализации именно порнографического дискурса.

Представленный образец актуализирует в иранских контекстах все архетипические роли, которые приписываются женщинам и визуализируются при помощи обнаженного, или почти обнаженного женского тела, в современной западной порно-культуре. Данная

реклама актуализирует диапазон возможных ролей женского тела в современной массовой культуре общества потребления, включая горничную, полицейскую, медсестру, спортсменку, несмотря на формальное доминирование строгих религиозных норм и предписаний.

Fig. 40. An advertisement for an online lingerie store in Iran.

This advertisement is an example of aggressive marketing based on the actualization of a sexualized or even pornified feminine body image. In the context of Iran's Islamist regime, this online store lists "the sale of shorts, fashionable bras, and lingerie" as its specialty, indicating that "shipping to all corners of Iran is possible" (Gāleri-ye āntik... 2021). Despite the official prohibition of porn in Iran, some samples of advertising products are based on the actualization of 
pornographic discourse. The presented sample actualizes in Iranian contexts all the archetypal roles attributed to women and visualized through the nude, or nearly nude female body, in contemporary Western porn culture. This advertisement actualizes the range of possible roles of the female body in today's mass culture of consumer society, including maid, policewoman, nurse, athlete, despite the formal dominance of strict religious norms and prescriptions.

\section{Список литературы}

Abdi, N. (1384). Āšnāyi bā makāteb-e naqqāši. Tehrān: Šerkat-e cāp-o našr-e ketābhā-ye darsi-ye Irān. (In Farsi).

Andriadze, D. (2011, February 6). Mkhat'vrul-disk'ursuli sivrtsis k'at'egoriata tezaurusi. Retrieved from Semiotics website: https://semioticsjournal.wordpress.com/2011/02/06/(In Georgian)

Berikašvili, T. (2012, December 12). Ident'obis p'roblema tanamedrove samq'aroši. Retrieved from Semiotics website: https://semioticsjournal.wordpress.com/2012/12/12/

Bucar, E. (2017). Pious Fashion. How Muslim Women Dress. Harvard: Harvard University Press.

Bucar, E. (2018, February 14). How Iranian women turn "pious fashion" into under-the-radar dissent. Retrieved from Zócalo Public Square website: https://www.zocalopublicsquare.org/ 2018/02/14/iranian-women-turn-pious-fashion-radar-dissent/ideas/essay/

Diba, L. S. (2012). Clothing in the Safavid and Qajar periods. In Encyclopaedia Iranica (Vol. 8, pp. 785808). Retrieved from http://www.iranicaonline.org/articles/clothing- $x$

Esfandiari, H. (1997a). Reconstructed Lives: Women and Iran's Islamic Revolution. New York: Woodrow Wilson Center Press and Johns Hopkins University Press.

Esfandiari, H. (1997b, October 13). Reconstructed Lives: Women and Iran's Islamic Revolution [Wilson Center]. Retrieved from https://www.wilsoncenter.org/article/reconstructed-lives-womenand-irans-islamic-revolution

Gāleri-ye āntik... 2021. (2021). Retrieved from Facebook website: https://www.facebook.com/ 146696625475439 (In Farsi)

Gery, B. (1392). Naqqāši-ye irāni. Tehrān: Donyā-ye now. (In Farsi).

Hobsbawm, E., \& Ranger, T. (Eds.). (1983). The Invention of Tradition. Cambridge: Cambridge University Press.

Hot Golshifteh Farahani Photos Are So Damn Hot That You Can't Hold Them. (2019). Retrieved from https://yogahealthsolution.com/49-hot-golshifteh-farahani-photos-are-so-damn-hot-thatyou-cant-hold-them/

Iranian women undress to protest their role as second-class citizens. (2012, March 8). Retrieved from The Observers-France 24 website: https://observers.france24.com/en/20120308-iranianwomen-get-naked-defend-rights-over-bodies-nude-video-calendar-goldshifteh-farahanialiaa-al-mahdy

Knox, P. (2019, July 5). 'No respect for women': Iranian model forced to flee her home country as she faced public lashing for half-naked photoshoot. Retrieved from The Sun website: https:// www.thesun.co.uk/news/9442855/iranian-model-homeless-paris-asylum-lashed-halfnaked-photos/

Leymarie, Y. (2017). Hadith mae shabat iiraniat hawl huquq almar'at walhayaat aljinsiat fi mawtiniha. Retrieved from https://ar.globalvoices.org/2018/07/09/58046/(In Arabic) 
Memarian, O. (2012, January 20). Nude Photo of Iranian Actress Golshifteh Farahani Roils Iran: A nude photo and breast-baring video of actress Golshifteh Farahani have divided Iranians. The Daily Beast. Retrieved from https://www.thedailybeast.com/articles/2012/01/20/nude-photo-ofiranian-actress-golshifteh-farahani-roils-iran

Pakbaz, R. (1396). Naqqāši-ye Irān: Az dirbāz tā emruz. Tehrān: Zarrin-o simin. (In Farsi).

Robinson, B. W. (1958). Descriptive Catalogue of the Persian Painting in Bodlean Library. Oxford: Oxford Unoversity Press.

Robinson, J. (2016, December 7). Twelve fashion bloggers and social media models are jailed in Iran for 'spreading prostitution and a Western-style culture of nudity'. Retrieved from Mail Online website: http://www.dailymail.co.uk/ /article-4008684/index.html

Set-e lebās-e fāntezi dāman-i jurāb-e dār-e model-e 2020. (2020). Retrieved from https:// lebaskhab.com/product/fantasy-set-dress-skirt-with-sock-model-2020/ (In Farsi)

Sharifi, N. (2018). Female Bodies and Sexuality in Iran and the Search for Defiance. London; New York: Palgrave Macmillan.

Silavi, M. (2019, December 11). The objectification of women in Iran. Retrieved from Baltimore Sun website: https://www.baltimoresun.com/opinion/op-ed/bs-ed-op-1211-objectificationwoman-iran-20191211-n2lqcxv7q5ehbnaqjd4qemez74-story.html

Tāvusi, A. (1391). Kārgāh-e negārgari. Tehrān: Šerkat-e cāp-o našr-e ketābhā-ye darsi-ye Irān. (In Farsi).

Амиранашвили, Ш. (1940). Иранская станковая живописъ. Тбилиси: Музей истории культуры и искусства.

Багдасарова, С. (2021a). Выставка гаремных красавиц-персиянок. В Музее Востока показывают яркое искусство эпохи Каджаров. Извлечено от Яндекс.Дзен website: https:// zen.yandex.ru/media/shakko/vystavka-garemnyh-krasavicpersiianok609f805b46cbf11541f0499e

Багдасарова, С. (2021b, май 17). Каджары: Декадентская роскошь в Музее Востока. Извлечено от The Art Newspaper Russia website: https://www.theartnewspaper.ru/posts/9070/

Баласеску, А. (2019). Тегеранский шик: Исламские платки, модельеры и новая география современности. Теория моды: одежда, тело, культура, (53). Извлечено от http:// www.nlobooks.ru/magazines/teoriya_mody/53_tm_3_2019/article/21633/

Боултвуд, Э., \& Джеррард, Р. (2021). Идея двойственности, мода и тело. Теория моды: одежда, тело, культура, (59). Извлечено от http://www.nlobooks.ru/magazines/teoriya_mody/ tm_59_1_2021/article/23374/

Васильева, Д. (2017). О фрагментах сефевидского бархата на переплете «Хамсе» Низами из собрания Российской национальной библиотеки. В Н. Дьяков \& А. Матвеев (Ред.), Азия u Африка: Наследие и современность. XXIX Международный конгресс по источниковедению и историографии стран Азии и Африки, 21-23 июня 2017 г.: Материалы конгресса (сс. 122-132). Санкт-Петербург: «НП Принт».

Васильева, Е. (2017). Система традиционного и принцип моды. Теория моды: одежда, тело, культура, (43). Извлечено от https://www.nlobooks.ru/magazines/teoriya_mody/ 43_tm_1_2017/article/12421/

Гасанова, Н. (2018, апрель 18). Искусство Ирана. Каджарская живопись (конец XVIII - XIX вв.). Извлечено от Искусство website: https://obiskusstve.com/1401420391620807307/ iskusstvo-irana-kadzharskaya-zhivopis-konets-xviii---xix-vv/ 
Гасымов, Р. (2016, апрель 7). Шарм и очарование Востока: Шедевры Каджарской живописи. Извлечено от https://ann.az/ru/sharm-i-ocharovanie-vostoka-shedevry-kadzharskoyzhivopisi/

Григорьева, Т. (2021, май 15). Что посмотреть на выставке «Роскошь заката: Иран эпохи Каджаров». Извлечено от Культура.РФ website: https://www.culture.ru/materials/ 256428/chto-posmotret-na-vystavke-roskosh-zakata-iran-epokhi-kadzharov

Демиденко, Ю. (2016). Белье и реклама: Взгляд мужской и взгляд женский. Теория моды: одежда, тело, культура, (41). Извлечено от https://www.nlobooks.ru/magazines/teoriya_mody/ 41_tm_3_2016/article/12024/

Деннике, Б. (1938). Живопись Ирана. Москва: Искусство.

Єрьоменко, Н. (2015). Чому селфі - це корисно? [Почему селфи - это полезно?]. Извлечено от Korydor. Журнал про сучасну культуру website: http://www.korydor.in.ua/ua/censure/ chomu-selfi-tse-korysno.html (In Ukranian)

Ибрагимов, Т. (2013). Живописъ каджарского периода. Баку: Издательский Дом "Şərq-Qərb".

Искусство Ирана в Музее Востока: Виртуальная экскурсия по выставке. (2020, апрель 15). Извлечено от Точка-Apт website: https://magazineart.art/online/iskusstvo-irana-v-muzeevostoka-virtualnaja-jekskursija-po-vystavke/

История моды. Молодая персидская дама «в европейском вкусе» и Богини Крита. (2013). Извлечено от LiveJournal website: https://gorbutovich.livejournal.com/40343.html

Кондаков, И. В. (2019). Русский масскульт: От барокко к постмодерну. Москва - Санкт-Петербург: Центр гуманитарных инициатив.

Лекомцева, Н. (2019, июль 6). Иранской модели пришлось бежать из страны после снимков в белье. Извлечено от Cosmopolitan website: https://www.cosmo.ru/lifestyle/news/06-072019/iranskoy-modeli-prishlos-bezhat-iz-strany-posle-snimkov-v-bele/

Махлина, С. Т. (2009). Семиотика культуры повседневности. Санкт-Петербург: Издательство Алетейя.

Новокшонова, Н. О. (2020). Міфологізація та образ жінки у дискурсах масової культури постмодерну [Мифологизация и образ женщины в дискурсах массовой культуры постмодерна]. Grani, 23(5), 28-38. doi: 10.15421/172050 (In Ukrainian)

Сироткина, И. (2021). Тело снова в моде: Корпореальность в эпоху пандемии. Теория моды: одежда, тело, культура, (59). Извлечено от https://www.nlobooks.ru/magazines/ teoriya_mody/tm_59_1_2021/article/23376/

Хессельбайн, К. (2019). Выход на подиум: От «одетого тела» к воплощению идентичности в телеи-одежде. Теория моды: одежда, тело, культура, (54). Извлечено от https:// www.nlobooks.ru/magazines/teoriya_mody/54_tm_4_2019/article/21865/

Хомейни, Р. М. (2011). Место и значение женщины в идеях имама Хомейни. Москва: Пробел-2000.

Цырлина, Я. (2018). Открыть тело: Презентация женского тела в искусстве XX - XXI веков. Извлечено от Permm website: https://permm.ru/ /otkryt-telo-yana-tsyrlina

Янсен, А. (2021). Мода и фантасмагория современности: Введение в деколониальный дискурс о моде. Теория моды: одежда, тело, культура, (59). Извлечено от https:// www.nlobooks.ru/magazines/teoriya_mody/tm_59_1_2021/article/23371/ 


\section{References}

Abdi, N. (1384). Āšnāyi bā makāteb-e naqqā̌̌i. Tehrān: Šerkat-e cāp-o našr-e ketābhā-ye darsi-ye Irān. (In Farsi).

Amiranashvili, Sh. (1940). Iranian easel painting. Tbilisi: Museum of the History of Culture and Art. (In Russian).

Andriadze, D. (2011, February 6). Mkhat'vrul-disk'ursuli sivrtsis k'at'egoriata tezaurusi. Retrieved from Semiotics website: https://semioticsjournal.wordpress.com/2011/02/06/(In Georgian)

Bagdasarova, S. (2021a). Exhibition of harem beauties of Persian women. The Museum of Oriental Art shows vibrant art from the Qajar era. Retrieved from Yandex.Zen website: https:// zen.yandex.ru/media/shakko/vystavka-garemnyh-krasavicpersiianok609f805b46cbf11541f0499e (In Russian).

Bagdasarova, S. (2021b, May 17). The Qajars: Decadent Luxury at the Museum of the Orient. Retrieved from. The Art Newspaper Russia website: https://www.theartnewspaper.ru/posts/9070/ (In Russian).

Balasescu, A. (2019). Tehran chic: Islamic shawls, fashion designers, and the new geography of modernity. Fashion Theory: Apparel, Body, Culture, (53). Retrieved from http:// www.nlobooks.ru/magazines/teoriya_mody/53_tm_3_2019/article/21633/(In Russian).

Berikašvili, T. (2012, December 12). Ident'obis p'roblema tanamedrove samq'aroši. Retrieved from Semiotics website: https://semioticsjournal.wordpress.com/2012/12/12/

Boultwood, E., \& Gerrard, R. (2021). The idea of duality, fashion, and the body. Fashion Theory: Apparel, Body, Culture, (59). Retrieved from http://www.nlobooks.ru/magazines/teoriya_mody/ tm_59_1_2021/article/23374/(In Russian).

Bucar, E. (2017). Pious Fashion. How Muslim Women Dress. Harvard: Harvard University Press.

Bucar, E. (2018, February 14). How Iranian women turn "pious fashion" into under-the-radar dissent. Retrieved from Zócalo Public Square website: https://www.zocalopublicsquare.org/ 2018/02/14/iranian-women-turn-pious-fashion-radar-dissent/ideas/essay/

Demidenko, Y. (2016). Lingerie and advertising: A male perspective and a female perspective. Fashion theory: clothing, body, culture, (41). Retrieved from https://www.nlobooks.ru/magazines/ teoriya_mody/41_tm_3_2016/article/12024/(In Russian).

Dennicke, B. (1938). Iranian Art. Moscow: Art. (In Russian).

Diba, L. S. (2012). Clothing in the Safavid and Qajar periods. In Encyclopaedia Iranica (Vol. 8, pp. 785808). Retrieved from http://www.iranicaonline.org/articles/clothing-x

Esfandiari, H. (1997a). Reconstructed Lives: Women and Iran's Islamic Revolution. New York: Woodrow Wilson Center Press and Johns Hopkins University Press.

Esfandiari, H. (1997b, October 13). Reconstructed Lives: Women and Iran's Islamic Revolution [Wilson Center]. Retrieved from https://www.wilsoncenter.org/article/reconstructed-lives-womenand-irans-islamic-revolution

Fashion History. A Young Persian Lady "in European Taste" and the Goddesses of Crete. (2013). Retrieved from LiveJournal website: https://gorbutovich.livejournal.com/40343.html (In Russian).

Gāleri-ye āntik... 2021. (2021). Retrieved from Facebook website: https://www.facebook.com/ 146696625475439 (In Farsi) 
Gasymov, R. (2016, April 7). Charm and Charm of the East: Masterpieces of Kajar painting. Retrieved from https://ann.az/ru/sharm-i-ocharovanie-vostoka-shedevry-kadzharskoy-zhivopisi/ (In Russian).

Gery, B. (1392). Naqqāši-ye irāni. Tehrān: Donyā-ye now. (In Farsi).

Grigorieva, T. (2021, May 15). What to see at the exhibition "Sunset Luxury: Qajar Era Iran". Retrieved from Culture.RF website: https://www.culture.ru/materials/256428/chto-posmotret-navystavke-roskosh-zakata-iran-epokhi-kadzharov (In Russian).

Hasanova, N. (2018, April 18). The Art of Iran. Qajar painting (late 18th - 19th centuries). Retrieved from Art website: https://obiskusstve.com/1401420391620807307/iskusstvo-irana-kadzharskayazhivopis-konets-xviii---xix-vv/ (In Russian).

Hesselbein, K. (2019). Going out on the runway: From the "clothed body" to the embodiment of identity in body-and-clothing. Fashion Theory: Apparel, Body, Culture, (54). Retrieved from https://www.nlobooks.ru/magazines/teoriya_mody/54_tm_4_2019/article/21865/(In Russian).

Hobsbawm, E., \& Ranger, T. (Eds.). (1983). The Invention of Tradition. Cambridge: Cambridge University Press.

Hot Golshifteh Farahani Photos Are So Damn Hot That You Can't Hold Them. (2019). Retrieved from https://yogahealthsolution.com/49-hot-golshifteh-farahani-photos-are-so-damn-hot-thatyou-cant-hold-them/

Ibragimov, T. (2013). Painting of the Qajar period. Baku: Publishing House "Şərq-Qərb". (In Russian).

Iranian women undress to protest their role as second-class citizens. (2012, March 8). Retrieved from The Observers-France 24 website: https://observers.france24.com/en/20120308-iranianwomen-get-naked-defend-rights-over-bodies-nude-video-calendar-goldshifteh-farahanialiaa-al-mahdy

Jansen, A. (2021). Fashion and the Phantasmagoria of Modernity: An Introduction to Decolonial Discourse on Fashion. Fashion Theory: Apparel, Body, Culture, (59). Retrieved from https:// www.nlobooks.ru/magazines/teoriya_mody/tm_59_1_2021/article/23371/(In Russian).

Khomeini, R. M. (2011). The Place and Meaning of Women in the Ideas of Imam Khomeini. Moscow: Probel-2000.. (In Russian).

Knox, P. (2019, July 5). 'No respect for women': Iranian model forced to flee her home country as she faced public lashing for half-naked photoshoot. Retrieved from The Sun website: https:// www.thesun.co.uk/news/9442855/iranian-model-homeless-paris-asylum-lashed-halfnaked-photos/

Kondakov, I. V. (2019). Russian Mass Culture: From Baroque to Postmodern. Moscow - St. Petersburg: Center for Humanitarian Initiatives. (In Russian).

Lekomtseva, N. (2019, July 6). Iranian model had to flee the country after underwear photos. Retrieved from Cosmopolitan website: https://www.cosmo.ru/lifestyle/news/06-07-2019/iranskoymodeli-prishlos-bezhat-iz-strany-posle-snimkov-v-bele/(In Russian).

Leymarie, Y. (2017). Hadith mae shabat iiraniat hawl huquq almar'at walhayaat aljinsiat fi mawtiniha. Retrieved from https://ar.globalvoices.org/2018/07/09/58046/(In Arabic)

Makhlina, S. T. (2009). Semiotics of Everyday Culture. St. Petersburg: Aletheia Publishers. (In Russian).

Memarian, O. (2012, January 20). Nude Photo of Iranian Actress Golshifteh Farahani Roils Iran: A nude photo and breast-baring video of actress Golshifteh Farahani have divided Iranians. The Daily 
Beast. Retrieved from https://www.thedailybeast.com/articles/2012/01/20/nude-photo-ofiranian-actress-golshifteh-farahani-roils-iran

Novokshonova, N. O. (2020). Mythologization and the Image of a Woman in Discourses of Postmodern Mass Culture. Grani, 23(5), 28-38. doi: 10.15421/172050 (In Ukrainian)

Pakbaz, R. (1396). Naqqāši-ye Irān: Az dirbāz tā emruz. Tehrān: Zarrin-o simin. (In Farsi).

Robinson, B. W. (1958). Descriptive Catalogue of the Persian Painting in Bodlean Library. Oxford: Oxford Unoversity Press.

Robinson, J. (2016, December 7). Twelve fashion bloggers and social media models are jailed in Iran for 'spreading prostitution and a Western-style culture of nudity'. Retrieved from Mail Online website: http://www.dailymail.co.uk/ /article-4008684/index.html

Set-e lebās-e fāntezi dāman-i jurāb-e dār-e model-e 2020. (2020). Retrieved from https:// lebaskhab.com/product/fantasy-set-dress-skirt-with-sock-model-2020/ (In Farsi)

Sharifi, N. (2018). Female Bodies and Sexuality in Iran and the Search for Defiance. London; New York: Palgrave Macmillan.

Silavi, M. (2019, December 11). The objectification of women in Iran. Retrieved from Baltimore Sun website: https://www.baltimoresun.com/opinion/op-ed/bs-ed-op-1211-objectificationwoman-iran-20191211-n2lqcxv7q5ehbnaqjd4qemez74-story.html

Sirotkina, I. (2021). The Body is Back in Fashion: Corporeality in the Age of Pandemic. Fashion Theory: Apparel, Body, Culture, (59). Retrieved from https://www.nlobooks.ru/magazines/ teoriya_mody/tm_59_1_2021/article/23376/(In Russian).

Stryomenko, N. (2015). Why are selfies useful? Retrieved from Korydor website: http:// www.korydor.in.ua/ua/censure/chomu-selfi-tse-korysno.html (In Ukrainian)

Tāvusi, A. (1391). Kārgāh-e negārgari. Tehrān: Šerkat-e cāp-o našr-e ketābhā-ye darsi-ye Irān. (In Farsi).

The Art of Iran at the Museum of Oriental Art: A Virtual Tour of the Exhibition. (2020, April 15). Retrieved from PointArt website: https://magazineart.art/online/iskusstvo-irana-v-muzeevostoka-virtualnaja-jekskursija-po-vystavke/ (In Russian).

Tsyrlina, Y. (2018). Discovering the Body: The Presentation of the Female Body in the Art of the Twentieth and Twenty-First Centuries. Retrieved from Permm website: https://permm.ru/ /otkryt-telo-yana-tsyrlina (In Russian).

Vasilyeva, D. (2017). Fragments of Safavid velvet on the binding of Nizami's "Khamsa" from the collection of the Russian National Library. In H. Dyakov \& A. Matveev (Eds.), Asia and Africa: Heritage and Modernity. XXIX International Congress on Source and Historiography of Asia and Africa, June 21-23, 2017: Proceedings of the Congress (pp. 122-132). St. Petersburg: NP Print. (In Russian).

Vasilyeva, E. (2017). The system of traditional and the principle of fashion. Fashion theory: clothes, body, culture, (43). Retrieved from https://www.nlobooks.ru/magazines/teoriya_mody/ 43_tm_1_2017/article/12421/(In Russian). 